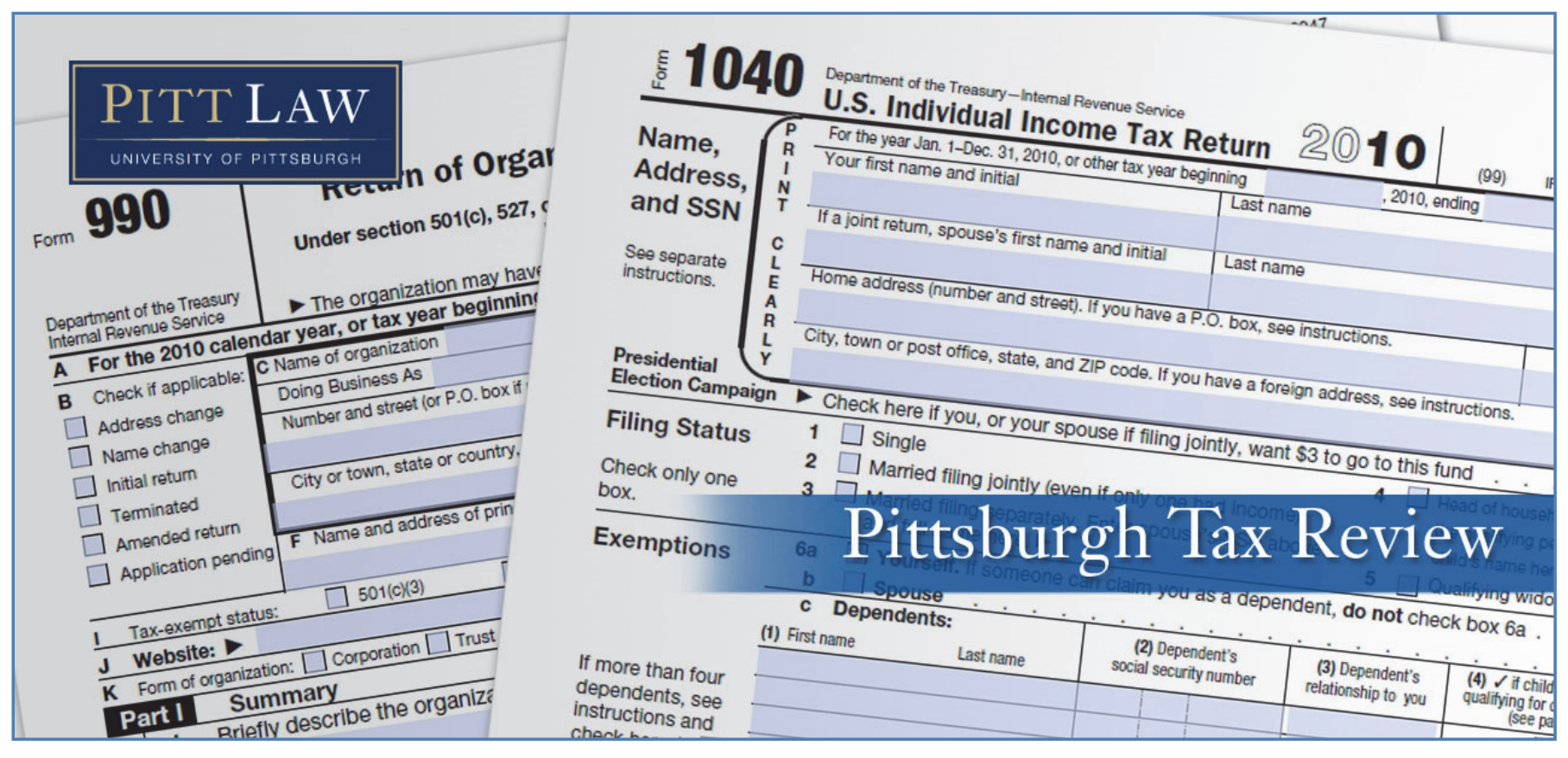

Volume 18 (2020) | ISSN 1932-1821 (print) 1932-1996 (online)

DOI 10.5195/taxreview.2020.119 | http://taxreview.law.pitt.edu

EVERY TAXPAYER COUNTS:

NINA OLSON'S IMPACT ON LOW-INCOME TAXPAYER CLINICS

\title{
T. Keith Fogg
}

\section{(cc) EY-NC-ND}

This work is licensed under a Creative Commons Attribution-Noncommercial-No Derivative Works 3.0 United States License.

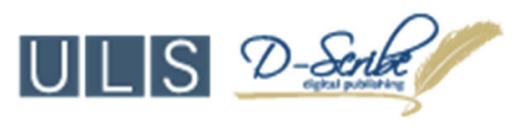

This journal is published by the University Library System of the University of Pittsburgh as part of its D-Scribe Digital Publishing Program, and is cosponsored by the University of Pittsburgh Press. 


\title{
EVERY TAXPAYER COUNTS: NINA OLSON'S IMPACT ON LOW-INCOME TAXPAYER CLINICS
}

\author{
T. Keith Fogg*
}

\section{INTRODUCTION}

This Article seeks to identify and discuss the impact of Nina Olson, in her role as National Taxpayer Advocate (NTA), on low-income taxpayer clinics (LITCs). ${ }^{1}$ Before discussing her impact in Part III of this Article, Part I will address her background prior to becoming the NTA, and Part II will discuss the situation with LITCs before she became the NTA. The scenesetting sections will be relatively short but provide necessary context for anyone not deeply knowledgeable about Nina or LITCs. ${ }^{2}$

* Clinical Professor and Director of the Tax Clinic at the Legal Services Center of Harvard Law School. The author wishes to thank the many people who spoke with me and reviewed this article to provide ideas and feedback. In particular, I want to thank the current director of the Community Tax Law Project (CTLP), David Sams, who provided me with access to the documents at CTLP that reached back to its foundation and to the 2019 summer interns at CTLP, Cy Hudson, Tyler Moses, and Sam Rosenblatt, who worked with me to gather information and transform it for this article. My research assistant Shuyu Sun was instrumental in assisting me in pulling together resources to populate the footnotes.

${ }^{1}$ The tax procedure blog, Procedurally Taxing, ran a month-long tribute to Nina Olson during her final month as the NTA. For her impact in this position from a broad cross-section of the tax community, including many clinicians running low-income taxpayer clinics, look at the blog posts on that site during the month of July 2019. See, e.g., Armando Gomez, Reflections on the Impact of Nina Olson, PROCEDURALLY TAXING (July 31, 2019), https://procedurallytaxing.com/reflections-on-the-impact-ofnina-olson-by-armando-gomez/.

${ }^{2}$ In addition to providing context about Nina and LITCs, I feel the need to provide a little context about my background of working with Nina. She called me in the fall of 1992 to discuss her idea to start a low-income taxpayer clinic in Richmond, Virginia, based on the model of getting tax lawyers to provide pro bono assistance to taxpayers. At the time I was the District Counsel for the Internal Revenue Service (IRS) Chief Counsel's Office in Richmond. She was given my name by professors or the associate dean at Georgetown Law School where she was pursuing a Master of Laws (LLM) on a part-time basis commuting up from Chapel Hill, North Carolina, to attend classes. I thought her idea was exciting. We spoke for the better part of an hour. Once her clinic opened at the end of that year, it became a regular representative of taxpayers whose cases were in my office. So, we worked together as opponents. We worked together to convince the IRS to put out information about her clinic. We worked together to

Pitt Tax Review | ISSN 1932-1821 (print) 1932-1996 (online)

DOI 10.5195/taxreview.2020.119 | http://taxreview.law.pitt.edu 
On March 1, 2001, Nina Olson (who will generally be referred to in this Article as Nina), became the second National Taxpayer Advocate, succeeding Val Oveson who was the first. ${ }^{3}$ Section 1102 of the Internal Revenue Service Restructuring and Reform Act of 1998 created the position of NTA. ${ }^{4}$ Prior to the creation of the position of the NTA, the Internal Revenue Service (IRS) had an Ombudsman Office created two decades earlier. ${ }^{5}$ The office of the Ombudsman had many of the same functions as the Taxpayer Advocate Service in that it sought to assist taxpayers who were stuck in the system or had a hardship; however, many new responsibilities

convince the Tax Court to allow her to participate at calendar calls. I regularly invited her to speak to the interns at my office and she regularly invited me to speak at the lawyer recruitment programs she conducted. She took my class on bankruptcy and taxation at Georgetown in the LLM program. After she became the NTA in 2001, we did not cross paths very often for a few years until I retired from the Chief Counsel's Office and began directing an LITC in 2007 at Villanova Law School. Since that time, in our reversed roles of me as an LITC director and her at the IRS, we have worked together on many occasions and I have had the opportunity to closely observe her impact on LITCs. Because of that perspective, many of the statements in this Article may not contain the detailed citations common for an article in which the author does not have such a personal connection to the subject of the article.

${ }^{3}$ See Nina Olson, NTA Blog: A Personal Message from the National Taxpayer Advocate, TAXPAYER ADVOC. SERV. (Mar. 1, 2019), https://taxpayeradvocate.irs.gov/news/nta-personal-message? category $=$ Tax\%20News (stating Mar. 1, 2001, as her start date). In 1998, Val Oveson was appointed the first head of the Taxpayer Advocate Service (TAS). In this role, he did the hard work of building an organization from the ground up. Although the Ombudsman Office had existed for almost two decades, TAS was a new creature with different responsibilities. Mr. Oveson's background provided good training for this task. He was elected to state-wide office in Utah at the age of twenty-eight and held several responsible positions in the state, including that of Lieutenant Governor, for almost twenty years before his appointment to this newly created position. He served in the position for almost two years following his appointment on September 1, 1998. See I.R.S. News Release IR-00-58 (Aug. 17, 2000). By the time he left, TAS had over two thousand employees and operated in seventy-four offices around the country. For additional views on the advocate position in general and on Nina, see Robert A. Weinberger, The Inside Agitator, 164 TAX NOTES FED. 1077 (Aug. 12, 2019); Jasper L. Cummings, The Taxpayer Advocate and Chief Counsel Secrets, 163 TAX NOTES 1191 (May 20, 2019). Although neither held the title of Ombudsman, it is interesting that the first two NTAs selected have Nordic roots. The NTA position has strong roots in the Ombudsman position and the modern word "ombudsman" comes from Sweden, as did Nina's ancestors. Ombudsman, WIKIPEDIA, https://en.wikipedia.org/wiki/Ombudsman (last visited Jan. 4, 2019).

${ }^{4}$ Internal Revenue Service Restructuring and Reform Act of 1998, Pub. L. No. 105-206, § 1102(a), 112 Stat. 685, 697 (codified at I.R.C. § 7803(c) and creating a detailed recitation of the duties of the NTA).

${ }^{5}$ Heather B. Conoboy, A Wrong Step in the Right Direction: The National Taxpayer Advocate and the 1998 IRS Restructuring and Reform Act, 41 WM. \& MARY L. REV. 1401, 1404 (2000). The article collects other writings on the creation of the NTA and its predecessors. Id. at 1403-05. It predicts that the NTA will be ineffective similar to the ombudsman that preceded it. Id. at 1402, 1404.

Pitt Tax Review | ISSN 1932-1821 (print) 1932-1996 (online)

DOI 10.5195/taxreview.2020.119 | http://taxreview.law.pitt.edu 
were placed on the NTA, including the annual report to Congress and the ability to issue Taxpayer Assistance Orders. ${ }^{6}$

Mr. Oveson held the position of NTA for almost two years. He was instrumental in building the structure of the office with its field function across the United States. When Nina arrived on the scene in March 2001, she took over from the acting director of the Taxpayer Advocate Service (TAS), Henry Lamar. ${ }^{7}$ TAS and the rest of the IRS had no idea what her arrival would mean. Unlike Mr. Oveson who had a political background, Nina came from a background of direct taxpayer representation both before she started the Community Tax Law Project and thereafter. That background would greatly shape her tenure as NTA, just as she would greatly shape the position of NTA and its relationship to the rest of the IRS and to taxpayers in general.

\section{NINA's BACKGROUND PRIOR TO BECOMING NATIONAL TAXPAYER ADVOCATE}

Nina grew up in the Philadelphia area. She attended Bryn Mawr College as an undergraduate where she majored in fine arts and Greek. After college she worked as a professional painter but as she was drawn into the business world she began doing her own accounting work and then the accounting and tax work of others. She evolved into running a tax preparation and accounting firm in Chapel Hill, North Carolina, for sixteen years. As she did that work, she decided that she needed a law degree. Though both UNC and Duke had well-known law schools near where she lived, she needed to keep working. So, she chose the law school at North Carolina Central University, which offered night classes that would allow her to keep her day job while picking up her law degree. ${ }^{8}$

After she obtained her law degree in 1991, Nina decided that she needed to get an LLM degree in tax in order to really understand tax law. To obtain

\footnotetext{
${ }^{6} I d$. at $1404,1407$.

${ }^{7}$ I.R.S. News Release IR-01-02 (Jan. 4, 2001) (quoting Henry Lamar as the Acting Director of the Taxpayer Advocate Service).

${ }^{8}$ See generally Beth Rhea, To Educate and Advocate: The Community Tax Law Project Speaks Out for Low-Income People with Tax Trouble, VA. LAW., Jan. 1994, at 56-67. Some of the background information comes from this article and some from my own personal knowledge of Nina.
}

Pitt Tax Review | ISSN 1932-1821 (print) 1932-1996 (online) DOI 10.5195/taxreview.2020.119 | http://taxreview.law.pitt.edu 
that degree, she attended the program at Georgetown Law School, which offers the degree in a program primarily taught at night and primarily to students obtaining the degree part-time. She commuted to Georgetown from Chapel Hill by train and arranged her classes so that she could spend just one night in Washington, D.C. On that one night she would couch surf before heading back to North Carolina. At about the same time she was attending Georgetown, she also realized that she wanted to start a low-income taxpayer clinic (LITC). ${ }^{9}$ She reached this conclusion, in part, because she quickly realized that she did not want to do landlord tenant or criminal cases in order to fulfill her pro bono obligation as a lawyer. She was inspired by hearing a Tax Court judge speak about the high percentage of taxpayers coming before that court who were unrepresented. ${ }^{10}$ During her process of exploring options to start an LITC, she called me and we had the conversation discussed earlier in this Article. ${ }^{11}$

Nina started the Community Tax Law Project (CTLP) in 1992. As someone with a front row seat watching her start CTLP, I can say without hesitation that her energy and ability to make contacts was impressive. You can see from the early interview with the Virginia State Bar that even as she created CTLP she already had aspirations for its reach that went well beyond Richmond, Virginia. ${ }^{12}$ Because she had to eat and keep a roof over her head, she continued to take on private clients as she built up CTLP and obtained grants to fund its operation.

In addition to building CTLP from nothing, Nina quickly became engaged with the American Bar Association Tax Section and with the Virginia State Bar. She became the chair of the Tax Section's Low-Income Taxpayer Committee. She chaired a Pro Se/Pro Bono Task Force of the Tax Section's Court Procedure Committee. She also chaired the Virginia State Bar's Special Committee on Access to Legal Services. She was the 1999

\footnotetext{
${ }^{9}$ She finished her LLM at Georgetown after moving to Richmond and starting CTLP. As her professor in a course involving bankruptcy and taxation, we carpooled from Richmond to D.C. on the nights of that course resulting in many hours of discussion of the problems with the tax system and how it treated the poor.

${ }^{10}$ See Nina Olson, Why Pro Bono Service, VA. LAw., Dec. 1998, at 19 (providing a discussion of her vision of pro bono service by members of the tax community).

${ }^{11}$ See supra note 2.

${ }^{12}$ Olson, supra note 10 , at 20.
}

Pitt Tax Review | ISSN 1932-1821 (print) 1932-1996 (online) DOI 10.5195/taxreview.2020.119 | http://taxreview.law.pitt.edu 
recipient of the Virginia Bar Association's Pro Bono Publico Award and the 1999 recipient of the Richmond Bar Association's Pro Bono Publico Award. ${ }^{13}$

Perhaps her most important, and certainly her most visible work prior to becoming NTA involved testifying before Congress as part of the run up to the IRS Restructuring and Reform Act of 1998. She teamed up with Janet Spragens, the director of the tax clinic at American University, to put a face on low-income taxpayers caught up in the tax system. ${ }^{14}$ With the recent passage of the welfare-to-work provisions and the important role that the earned income tax credit played in that legislation, the timing was perfect and enhanced the role of representatives of low-income taxpayers. ${ }^{15}$ Nina and Janet were the perfect persons to fulfill that role. They made a huge impact through their testimony. ${ }^{16}$

\footnotetext{
${ }^{13}$ Nina Olson Named U.S. Taxpayer Advocate, VA. LAW. MAG., Feb. 2001, at 40. It took twenty more years before she received a similar award from the ABA Tax Section in 2019- she received the Janet Spragens Award for Pro Bono Service, the only annual award that the Tax Section gives to a member. See C. Wells Hall, III, Recipient of the 2019 Janet Spragens Pro Bono Award: Nina E. Olson, 38 ABA TAX TIMES, Feb. 2019, at 35-36. In fairness to the Tax Section, it did not have such an award in 1999. The creation of the award was due in no small part to the work that Nina did to promote the importance of pro bono work in the Tax Section.

${ }^{14}$ See generally Better Representation in Tax Courts Calendar Cases, 70 TAX Notes 1285 (1996) (showing views of Janet Spragens and how she influenced the formative thinking of LITCs via an exchange of letters with Hon. Peter Panuthos, Chief Special Trial Judge, United States Tax Court (Oct. 31, 1995-Nov. 22, 1995)); see also Janet Spragens, Student Tax Clinics, 81 TAX Notes 129, 130 (1998); Janet Spragens, Welfare Reform \& Tax Counseling; Overlooked Part of the Welfare Debate?, 73 TAX NOTES 353, 354 (1996) [hereinafter Spragens, Welfare Reform \& Tax Counseling]; Janet Spragens \& Nancy Abramowitz, IRS Modernization and Low-Income Taxpayers, 53 ADMIN. L. REV. 701, 706-07 (2001).

${ }^{15}$ See Personal Responsibility and Work Opportunity Act of 1996, Pub. L. No. 104-93, 110 Stat. 2105; see also Dennis J. Ventry, Jr., The Collision of Tax and Welfare Politics: The Political History of the Earned Income Tax Credit, 1969-99, in MAKING WORK PAY: THE EARNED INCOME TAX CREDIT AND ItS IMPACT ON AMERICA's FAMILIES 15-66 (Bruce D. Meyer \& Douglas Holtz-Eakin eds., 2001); Spragens, Welfare Reform \& Tax Counseling, supra note 14.

${ }^{16}$ NAT'L COMM’N ON RESTRUCTURING THE INTERNAL REVENUE SERV., A VISION FOR A NEW IRS, at C-5, C-9 (1997) (Janet Spragens testified before the Restructuring Commission on February 26, 1997, as one of three individuals in the "Taxpayer Representative" category. The report of the Restructuring Commission led directly to the adoption of grant funds for low-income taxpayer clinics and Janet Spragens's testimony led directly to the idea of creating the grant funds. Nina Olson is listed as one of the "Individuals Who Met with the Commission."); Taxpayer Rights: Written Comment and Hearing Before the Subcomm. on Oversight of the H. Comm. on Ways and Means, 105th Cong. 145 (1997) (On September 26, 1997, Nina testified at a hearing on the recommendations of the National Commission on
}

Pitt Tax Review | ISSN 1932-1821 (print) 1932-1996 (online) DOI 10.5195/taxreview.2020.119 | http://taxreview.law.pitt.edu 
The creation of $\S 7526$ and the grant program for LITCs certainly became the singular, most well-known result of their testimony but it was not the only piece of legislation that they influenced. In testifying, she also made an impression on people of influence and that led to her appointment as the second NTA. ${ }^{17}$ Nina and the LITC movement became intertwined as she had an outsize influence on the expansion of LITCs from a small and severely underfunded group to a much larger and less severely underfunded group while her testimony leading to the creation of the LITC grant program helped to propel her into a position of national prominence in the tax world.

\section{BACKGROUND OF LOW-INCOME TAXPAYER CLINICS PRIOR TO NINA BECOMING NATIONAL TAXPAYER ADVOCATE}

LITCs began in 1974 at Hofstra Law School. ${ }^{18}$ Shortly thereafter similar clinics opened at Southern Methodist University Law School and University of Michigan Law School. ${ }^{19}$ From the mid-1970s until the creation of CTLP in 1992, all LITCs were opened in academic institutions, primarily law schools. ${ }^{20}$ CTLP became the first nonacademic LITC and built itself on the model of pro bono representation by tax lawyers instead of student representation. ${ }^{21}$ Although some grant funding for clinics, including LITCs,

Restructuring the IRS on taxpayer protections and rights. Her testimony covered many issues presented by the Restructuring Commission's proposals. She focused, however, on the need for tax clinics and the need for funding for such clinics.); IRS Restructuring: Hearings on H.R. 2676 Before the S. Comm. on Fin., 105th Cong. 124-26 (1998) (statement of Nina E. Olson, Executive Director, Community Tax Law Project); id. at 329-36 (prepared statement of Nina E. Olson); id. at 336-40 (responses to questions from Senator Roth) (showing that Nina also testified before the Senate Finance Committee and submitted written remarks to that committee; her testimony focused on problems low-income taxpayers have contending with the IRS Collection Division, but she also spoke about the need for funding for lowincome taxpayer clinics); see also Janet Spragens \& Nina E. Olson, Tax Clinics: The New Face of Legal Services, 88 TAX NOTES 1525 (2000); Nina E. Olson, Low Income Taxpayer Clinics: The Means to a Fairer Tax System, CMTy. Tax L. ReP., Spring 1998, at 12; Joe Holley, Janet Spragens, 62; Law Professor Set Up Tax Clinic to Aid Poor, WASH. POST (Feb. 22, 2006), http://www.washingtonpost.com/ wp-dyn/content/article/2006/02/21/AR2006022101813.html.

${ }^{17}$ Gomez, supra note 1.

${ }^{18}$ See Keith Fogg, Taxation with Representation: The Creation and Development of Low-Income Taxpayer Clinics, 67 TAX LAW. 3, 5 (2013) (discussing LITCs in detail).

${ }^{19}$ Id. at 7.

${ }^{20} I d$. at 22 .

${ }^{21}$ Id.

Pitt Tax Review | ISSN 1932-1821 (print) 1932-1996 (online)

DOI 10.5195/taxreview.2020.119 | http://taxreview.law.pitt.edu 
existed in the 1980s though the Department of Education, it had dried up by the 1990s and growth in LITCs had virtually come to a standstill. ${ }^{22}$ Inspired by CTLP, a couple of other independent clinics had come into existence, but by 1998 when Congress passed $\S 7526$ creating grant funds for LITCs, only sixteen LITCs existed nationwide. ${ }^{23}$

Essentially, these "sweet sixteen" existing clinics were the ones with their hands out for the first dollop of grant money from $\S 7526 .{ }^{24} \mathrm{Just}$ as Nina did not become NTA until March 2001, the administration of the $\S 7526$ grant did not reside under TAS in the initial years. The IRS placed the administration of the grant into the Wage and Investment (W\&I) division after the initial year. ${ }^{25}$ The grant administration resided in W\&I for approximately three years until 2003 when it moved into TAS, where it has resided ever since. ${ }^{26}$

\section{${ }^{22} I d$. at 18 .}

${ }^{23} I d$. at 19.

${ }^{24}$ I still remember talking to Nina when she received the money. It did not come until late in the fiscal year, and she had a short period of time to spend it in August and September 1999. She told me she was going on a shopping spree at La Diff, a furniture store in Richmond that appealed to her artistic and fashion sensibilities. Some of the La Diff furniture purchased in 1999 still exists at CTLP at the time of the writing of this Article. Not all clinics seek the grant funds available through $\S 7526$. For example, the clinic at SMU Law School, the oldest continuously operating clinic, has never sought grant funds. Each clinic must make its own decision regarding the funds and the restrictions that come with the funds. While the vast majority of clinics seek the funds, a small number of LITCs operate without them.

${ }^{25}$ See I.R.S. News Release IR-00-67 (Sept. 27, 2000) (stating that the W\&I Division of the IRS came into existence in October, 2000); Internal Revenue Service Restructuring and Reform Act of 1998, Pub. L. No. 105-206, § 1001, 112 Stat. 685, 689. Although the initial "stand up" of W\&I was not until 2000 and the first grant cycle for LITCs was in 1999, parts of W\&I actually existed before 2000. Stakeholder Partnerships, Education \& Communication (SPEC) was formed in 1999 or so, and there was a unit within SPEC that administered the Volunteer Income Tax Assistance (VITA) program and the new LITC program. SPEC is the Outreach and Education arm of W\&I. So once W\&I formally stood up, the same unit continued to handle the LITC grants until W\&I handed over the reins to TAS. In the initial determination of what $\S 7526$ allowed LITCs to do, some dispute existed within the IRS and Chief Counsel's Office about the scope of the work and particularly concerning return preparation. That dispute continued over several years eventually evolving into a decision that LITCs would do controversy work and VITA sites would prepare returns. LITCs prepare returns only in connection with an ongoing controversy.

26 Treasury Inspector Gen. for Tax Admin., Ref. No. 2011-10-067, The TaXPayer Advocate Service Can More Effectively Ensure Low Income TaXPayer Clinics Are APPROPRIATELY USING GRANT FUNDS (2011), https://www.treasury.gov/tigta/auditreports/2011 reports/

Pitt Tax Review | ISSN 1932-1821 (print) 1932-1996 (online)

DOI 10.5195/taxreview.2020.119 | http://taxreview.law.pitt.edu 
The growth of LITCs in the first years after the passage of $\S 7526$ was rapid. ${ }^{27}$ The growth after TAS took over administration of the grant cooled down, but the clinics matured and many were capable of assisting more clients than during their formative years. ${ }^{28}$ So, Nina did not have an impact

$201110067 \mathrm{fr} . \mathrm{html}$ (stating that prior to the transfer of administration and oversight of the LITC program to TAS in May 2003, that function was performed by the W\&I Division). TAS:

${ }^{27}$ The below table shows the growth of LITCs in the early years before administration moved to

\begin{tabular}{|l|l|}
\hline 1998 & 16 LITCs \\
\hline 1999 & 34 LITCs from 43 grant applications \\
\hline 2000 & 70 LITCs from 88 grant applications \\
\hline 2001 & 102 LITCs from 141 grant applications \\
\hline 2002 & 127 LITCs \\
\hline 2003 & 138 LITCs \\
\hline
\end{tabular}

Fogg, supra note 18, at 3, 27.

${ }^{28}$ The growth of LITCs in the years after TAS took over:

\begin{tabular}{|l|l|}
\hline 2004 & 135 LITCs \\
\hline 2005 & 145 LITCs \\
\hline 2006 & 150 LITCs \\
\hline 2007 & 154 LITCs \\
\hline 2008 & 154 LITCs \\
\hline 2009 & 162 LITCs \\
\hline 2010 & 160 LITCs \\
\hline 2012 & 165 LITCs \\
\hline 2013 & 156 LITCs \\
\hline 2014 & 144 LITCs \\
\hline 2015 & 133 LITCs \\
\hline 2016 & 132 LITCs \\
\hline 2017 & 129 LITCs \\
\hline 2018 & 138 LITCs \\
\hline 2019 & 134 LITCs \\
\hline & 131 LITCs \\
\hline
\end{tabular}

Pitt Tax Review | ISSN 1932-1821 (print) 1932-1996 (online)

DOI 10.5195/taxreview.2020.119 | http://taxreview.law.pitt.edu 
on LITCs as the NTA until March 1, 2001, and had not much impact as the NTA until the administration of the LITC grant moved from W\&I to TAS. ${ }^{29}$ As discussed in Part II, she had a significant impact on LITCs from her position as director of CTLP, her testimony, and her position as chair of the Low-Income Taxpayer Committee of the ABA Tax Section from 1999 to $2001{ }^{30}$ Of course, she had a tremendous impact because of her testimony before Congress, along with Janet Spragens, which led to the creation of $\S 7526$ and the grant funds. ${ }^{31}$

CTLP and Nina started or continued some impactful projects in the few years between 1998 and 2001 that deserve some mention. She started a quarterly news bulletin aimed at providing information to LITCs. ${ }^{32}$ The news

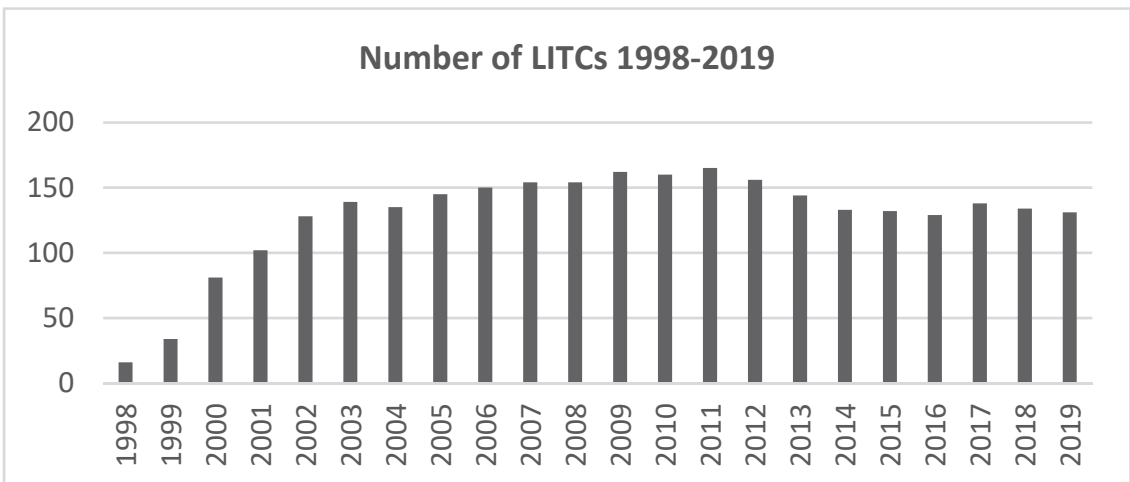

Id. See also I.R.S. Pub. No. 5066-A, Low Income Taxpayer Clinics Program Report (2015); I.R.S. News Release IR-16-32 (Feb. 26, 2016); I.R.S. Pub. No. 5066, Low Income Taxpayer Clinics Program Report (2018); I.R.S. Pub. No. 3319, Low Income Taxpayer Clinics: 2020 Grant Application Package and Guidelines (2019).

${ }^{29}$ TREASURY INSPECTOR GEN. FOR TAX ADMin., supra note 26.

${ }^{30}$ E-mail from Todd Reitzel, Dir. of Publ'g, ABA Tax Section, to T. Keith Fogg, Clinical Professor of Law, Harvard L. Sch. (Dec. 16, 2019, 02:29 EST) (on file with author) (confirming her time as committee chair).

${ }^{31}$ See NAT'L COMM'N ON RESTRUCTURING THE INTERNAL REVENUE SERV., supra note 16.

${ }^{32}$ See The Community Tax Law Report, CMTy. TAX L. PROJECT, http://www.ctlp.org/newsletter .html (last visited Jan. 4, 2020).

Pitt Tax Review | ISSN 1932-1821 (print) 1932-1996 (online) DOI 10.5195/taxreview.2020.119 | http://taxreview.law.pitt.edu 
bulletins contained articles from many leading practitioners and academics. ${ }^{33}$ They also contained practical articles on how to start a clinic written by Nina and by Janet Spragens. ${ }^{34}$ CTLP obtained grant funds from a combination of charitable sources allowing it to bring on an Equal Justice Works fellow for two years. ${ }^{35}$ She consulted with clinics to assist them in formation and in development. ${ }^{36}$ She held regular training sessions for tax practitioners that she made available on a broader scale. ${ }^{37}$ She convinced the state of Virginia bar foundation and the state legislature to provide a grant to CTLP. ${ }^{38}$

As clinics expanded in the wake of the grant funding becoming available, academic clinics fell into the background in terms of numbers and clinics housed within legal services organizations became the predominate type of LITC. The change in type of clinic from the academic clinics with a few independent clinics prior to the grant funds to clinics housed within legal

${ }^{33}$ See, e.g., Jerome Borison, A Cautionary Tale: Innocent Spouse Basics, CMTY. TAX L. REP., Apr. 1997, at 1; Gerald A. Kafka, The Ten Suggestions of Tax Court Practice for the First-Time Private Practitioner, CMTY. TAX L. REP., Spring 1998, at 7.

${ }^{34}$ See The Community Tax Law Report, supra note 32.

${ }^{35}$ This may be the first fellow to work in an LITC and may form the model for the Christine Brunswick Fellowship later created by the ABA Tax Section to provide assistance to low-income taxpayers. The fellow at CTLP, Anita Soucy, became a leading tax practitioner in her own right, including a stint in Treasury's Office of Tax Policy. To have someone trained out of law school to assist low-income taxpayers and then ascend to higher echelons of tax practice and tax policy making was itself a significant impact created by Nina during these years. The grant came from the National Legal Aid Defenders Association and was $50 \%$ funded by the Open Society Institution, $25 \%$ funded by the ABA Tax Section, and $25 \%$ funded by the Virginia Law Foundation.

${ }^{36}$ See, e.g., Nina E. Olson, Low Income Taxpayer Clinics: The Means to a Fairer Tax System, CMTY. TAX L. PROJECT, http://www.ctlp.org/independent_clinic.htm (last visited Jan. 4, 2020); Janet A. Spragens, A Checklist for Starting a Law School Tax Clinic, CMTY. TAX L. PROJECT, http://www.ctlp.org/ school_clinic.htm (last visited Jan. 4, 2020).

${ }^{37}$ See Training, CMTy. TAX L. ProJeCt, http://www.ctlp.org/training.html (last visited Jan. 4, 2020) (listing a number of free articles and continuing legal and professional education course packs which could be purchased through mail at http://www.ctlp.org/order.html).

38 See Taxpayer Advocate Report and Low-Income Taxpayer Clinics: Hearing Before the Subcomm. on Oversight of the H. Comm. on Ways and Means, 107th Cong. 48 (2001) (statement of Timothy B. Heavener, Executive Director CTLP) (stating that CTLP received a grant of $\$ 28,000$ from the Virginia Law Foundation and, with the help of $\S 7526$, would be able to reach out to additional resources such as the Commonwealth of Virginia, the Community Foundation, the National Associations of Public Interest Law, etc.). By obtaining funds from sources other than the IRS, she created a model for other clinics to go outside of the IRS for grant funds and build coalitions with the community in order to build and preserve their clinics. The Virginia legislature has a line item on the budget for the Virginia State Bar providing a direct grant to CTLP.

Pitt Tax Review | ISSN 1932-1821 (print) 1932-1996 (online)

DOI 10.5195/taxreview.2020.119 | $\underline{\text { http://taxreview.law.pitt.edu }}$ 
services organizations created some special needs for clinics and clinicians that did not exist prior to 1998. Someone with Nina's background in the clinic world could see and understand the differences between types of clinics and she experienced some of this prior to becoming the NTA.

\section{IMPACT OF NINA OLSON AS NTA ON LITCS}

This Part is divided into six subparts and seeks to group Nina's impact on clinics under one of these six headings. This Part provides details about Nina's impact by further breaking these subparts down to focus on specific areas of her impact. As discussed below, her impact on LITCs as the NTA encompasses a broad range of topics and reaches into almost every facet of LITC development and operation. It is hard to imagine almost any aspect of LITCs that she has not thought about and talked about at some point.

At the time Nina became NTA, over 130 clinics that received the grant under $\S 7526$ existed. ${ }^{39}$ At the time of her retirement over fifteen years later, the number of active clinics receiving the grant had not changed much. ${ }^{40}$ The work of the clinics during that period changed substantially as shown by the number of clinics handling Tax Court cases, the number of comments on regulations and subregulatory guidance, and the number of cases litigated in the Circuit Courts of Appeal. During Nina's time as NTA, many new clinics came into existence and many clinics that existed when she arrived ceased to exist. ${ }^{41}$ She has influenced both the existing clinics and the ones that developed under her tenure as NTA. This Part seeks to chronicle the many ways she has influenced clinics.

Perhaps the discussion should start with money since most of these clinics would not exist without the grant. ${ }^{42}$ Her testimony, and other efforts, that helped to persuade Congress to pass $\S 7526$ as part of the IRS Restructuring and Reform Act of 1998 cannot be overlooked as perhaps her greatest benefit to LITCs because it effectively kick-started the development of almost ten times as many LITCs as existed at the time she testified;

\footnotetext{
${ }^{39}$ Fogg, supra note 18, at 27.

${ }^{40}$ Fogg, supra note 28.

${ }^{41}$ See id.

${ }^{42}$ Compare the number of clinics in existence in 1998 before the grant with the number of clinics that arose thereafter. See id. Clinics increased by almost tenfold.
}

Pitt Tax Review | ISSN 1932-1821 (print) 1932-1996 (online) DOI 10.5195/taxreview.2020.119 | http://taxreview.law.pitt.edu 
however, her work as NTA caused LITCs to mature into a powerful voice for low-income taxpayers and the tax system as a whole. She did not stop her work with Congress after persuading it at one moment in time to create a grant program to fund LITCs, but she continued her work over two decades to ensure that the implied promise of benefits resulting from the creation of the grant fulfilled the vision.

Because of her continued leadership, Congress has continued to fund and to expand the grant program. ${ }^{43}$ She not only envisioned what the grants could do but she also implemented procedures to ensure the fulfillment of the vision. Nina will also quickly point out that "her" impact on LITCs during her time as NTA was part of a team effort. She regularly mentions the names of many individuals who assisted her in making this impact by making suggestions or carrying out the necessary implementation tasks. This Article will not pay tribute to all of those individuals by name but acknowledges the contributions of many, working under Nina's leadership, in achieving the items described below.

\section{A. Changes to Clinic Structure}

From their start in 1974, LITCs operated primarily in an independent fashion without many unifying forces pulling them together. From 1974 to 1998, they grew without any oversight and new clinics developed primarily as a result of one person's activism at an academic institution. The ABA Tax Section provided some glue to bond the group by publishing a handbook created by some of the clinicians, by initiating a listserv, and by offering the opportunity for committee work, but the small group of LITCs in existence operated fairly independently of each other. ${ }^{44}$ The creation of the grant caused an explosion in the number of clinics but also a need for greater forces to cause the community to come together. The early overseers of the grant at the IRS did not take up the mantle to provide community building. In 1999, Janet Spragens began hosting a conference for LITCs at American University

\footnotetext{
${ }^{43}$ See infra Part IV.B.

${ }^{44}$ Jerry Borison and a few other academic clinicians started the handbook Effectively Representing Your Client Before the IRS in the early 1990s. The ABA Tax Section published the book. Jerry also started a listserv which the ABA Tax Section eventually hosted, and the ABA Tax Section had a committee dedicated to low-income taxpayers which served as the primary gathering point for the band of early clinicians.
}

Pitt Tax Review | ISSN 1932-1821 (print) 1932-1996 (online) DOI 10.5195/taxreview.2020.119 | http://taxreview.law.pitt.edu 
as a start at this community building. ${ }^{45}$ When the grant administration moved from W\&I to TAS, Nina began in earnest to forge the group not only with an annual conference but also in many other ways. ${ }^{46}$

1. She changed the method of evaluating LITCs. ${ }^{47}$ For those working in LITCs it might be easy just to say she made the grant application much more difficult to prepare by requiring the LITCs to gather much more data than previously required for the grant submissions. ${ }^{48}$ Despite the additional burden of the information required over the years, the information allowed TAS not only to evaluate the effectiveness of the programs and to shape the type of work they performed but also to sell the programs. For purposes of this discussion, the focus centers on evaluating LITCs, even though the method had other goals as well.

At first, it appeared that the changes to Publication 3319 focused almost exclusively on the number of cases/issues worked. When clinicians, and especially academic clinicians, pushed back on the use of only case metrics, she adjusted the method to take into account writing, impact litigation and amicus briefs, and other items that could have a broader impact on the community of LITCs

${ }^{45}$ In 2005, she held her sixth, and last, conference on low-income tax issues at American University. She also testified for the fourth time before the IRS Oversight Board on February 1, 2005. See Janet Spragens, Statement Before the IRS Oversight Board (2005).

${ }^{46}$ Fogg, supra note 18, at 27-31.

${ }^{47}$ I start with this example of the way Nina has influenced LITCs because she has used the grant evaluation process to shape and drive the LITCs. She could see that the method of evaluating clinics and rewarding them with grant dollars could motivate clinics to follow her vision for their performance. She could also see that creating a body of hard data would better enable her to continue to sell the program to Congress. While the method of evaluating LITCs may appear as a mundane matter to discuss as one of her achievements with LITCs, this may represent her greatest achievement in molding the LITCs to perform the work for low-income taxpayers that she envisioned.

${ }^{48}$ See infra Appendix A, which contains an analysis of the grant reporting requirements as set out in Publication 3319. The number of pages of each of the publications provides one measure of the increasing burden of grant reporting. In 2001, this publication ran forty-two pages and by 2019 it had increased to 210 pages. Of course, pages alone do not tell the whole story, and Appendix A tries to capture the additional requirements over the arc of time. Not all of the pages of Publication 3319 concern reporting requirements. The publication also serves as the rules of the road for LITCs. As of this writing, the IRS has never published regulations under $\S 7526$. Publication 3319 would incrementally increase each year to add additional program information that developed since the prior publication.

Pitt Tax Review | ISSN 1932-1821 (print) 1932-1996 (online)

DOI 10.5195/taxreview.2020.119 | http://taxreview.law.pitt.edu 
or the taxpayers they serve. ${ }^{49}$ By standardizing the reporting requirements she made the process of obtaining grants more equitable. By listening to feedback from the LITCs, she made the process more reflective of the varying strengths and weaknesses that different clinics bring to the overall program.

She developed performance measures for grantees that incorporate both standards of operation (e.g., with regard to staffing, access to a tax library, safeguarding client records, etc.) as well as metrics for the amount and types of cases worked and issues encountered, consultations provided, education activities presented, and outreach and systemic advocacy activities conducted. ${ }^{50}$

Appendix A provides an overview of the changing requirements over the arc of Nina Olson's time as NTA. For a fuller appreciation of the data required and the use of Publication 3139 to guide the LITCs to certain types of performance, see the publications themselves. ${ }^{51}$

2. Push for Productivity. Her push for productivity in representation led to a disagreement with some academic clinics. This issue receives some discussion above with respect to her vision for LITCs. She developed the first nonacademic LITC designed to assist the maximum number of taxpayers who faced a problem with the IRS. The quest for productivity struck a deeper chord in some of the academic clinics with long-standing programs that focused on education as much as or more than productivity. This created a bit of a rift between the NTA and her former ally at American University. A law review article by Nancy Abramowitz describes

${ }^{49}$ Compare I.R.S. Pub. No. 3319, Low Income Taxpayer Clinic: 2009 Grant Application Package and Guidelines app. c (2008) (where only case numbers and issues appear), with I.R.S. Pub. No. 3319, Low Income Taxpayer Clinics: 2013 Grant Application Package and Guidelines app. c (2012) (where the reporting of other work appears, making it possible for law review articles, blog posts, and other actions that might more likely occur in an academic clinic to influence the rating of the clinic's performance).

${ }^{50}$ See I.R.S. Pub. No. 3319, supra note 28; see also I.R.S. Form No. 13424-C, Low Income Taxpayer Clinic (LITC) Advocacy Information Report (2016) (requesting data about systemic advocacy submissions and published materials); I.R.S. Form No. 13424-A, Low Income Taxpayer Clinic (LITC) General Information Report (2016) (requesting account of outreach and educational activities).

${ }^{51}$ E.g., I.R.S. Pub. No. 3319, supra note 28.

Pitt Tax Review | ISSN 1932-1821 (print) 1932-1996 (online) DOI 10.5195/taxreview.2020.119 | http://taxreview.law.pitt.edu 
the important function that academic clinics played even when they were not representing a high volume of cases. ${ }^{52}$ While the NTA revised the measurements to a certain extent, she continued to hold LITCs accountable for a certain level of productivity in order to receive the highest grant award. ${ }^{53}$

Although a handful of clinics over the years saw their request for grant renewal denied due to underperformance or nonperformance, TAS usually chose to reduce the size of the grant awarded rather than to deny the grant outright. ${ }^{54}$ So many unrepresented taxpayers exist compared to the number of clinics available that the push for productivity by clinics makes sense as a goal for clinics generally and as a means by which to show the funder, in this case Congress, the value of LITCs. Showing Congress that clinicians wrote $\mathrm{X}$ number of law review articles or made comments on $Y$ number of regulations or subregulatory guidance makes for a much tougher sell when proving the value of the program. Getting LITCs to focus on productivity as a core aspect of their work helps to build the profile of LITCs as a fighting force for low-income taxpayers.

3. Directed grants to controversy clinics. Prior to 1998, English-asa-second-language (ESL) clinics did not exist as formal LITCs, although many community organizations may have conducted outreach to the ESL population regarding their tax obligations.

\footnotetext{
52 Nancy S. Abramowitz, Thinking About Conflicting Gravitational Pulls; LITCs: The Academy and the IRS, 56 AM. U. L. REV. 1127 (2007). Nancy served as Janet Spragens's long-time assistant before taking over as the director of the clinic at American University Law School when Janet could no longer direct the clinic due to illness. The article details the benefits of academic clinics not shackled to a program of high productivity. Some of the concerns expressed in the article were accepted by TAS and incorporated into the system of measuring clinics, such as articles published or impact litigation pursued. $I d$. at 1135. Other suggestions in the article that advocated for a system of evaluation not based on productivity were not accepted, leaving a standing disagreement in the philosophy behind LITCs located in academic clinics where productivity (i.e., number of clients served) remains a twin goal along with student development.

${ }^{53}$ I cannot cite data to support this statement but I believe it to be true based on discussions with those who reviewed the grants and statements made by Nina at LITC conferences. I do not intend to say that representing the highest number of taxpayers provided the only path to a high grant award; however, representing a low number of taxpayers would generally cause a reduced award to the LITC compared with other, more productive clinics. counsel.

${ }^{54}$ The author reached the conclusion after conversations with former TAS employees and their
}

Pitt Tax Review | ISSN 1932-1821 (print) 1932-1996 (online)

DOI 10.5195/taxreview.2020.119 | http://taxreview.law.pitt.edu 
Because of the language of $\S 7526$, some organizations sought grant funds solely for the purpose of educating the ESL community and not engaging in representation regarding tax controversies. Nina inherited the ESL-only clinics from the beginning of the program when it was overseen by W\&I. ${ }^{55}$ Looking at the bulletins written by CTLP, her desire to assist individuals in the ESL community easily comes through. ${ }^{56}$ Her focus on controversy did not reflect a lack of desire to assist individuals for whom English was their second language but rather a desire to more fully assist them. She wanted to make sure that these individuals not only understood the tax system of the United States but also that they had someone to guide them through the system when a controversy arose.

Building on the idea of productivity and client representation as the core function of LITCs, Nina decided that funding organizations that only provided outreach did not provide the best use of the limited grant funds she had available. Starting around 2014, she worked with the ESL-only clinics to convince them to establish a controversy practice in order to allow them to continue to receive the grant. She also pushed controversy clinics to expand their ESL outreach efforts since the stand-alone ESL clinics would no longer exist to perform that function. She did not ignore or denigrate working with the ESL population to help them understand and join the tax system of the United States, but she moved controversy to the primary position of focus for LITCs with ESL as an important secondary focus.

55 I.R.C. $\$ 7526(\mathrm{~b})(1)(\mathrm{A})$ (contemplating this possibility: "The term "qualified low-income taxpayer clinic' means a clinic that- does not charge more than a nominal fee for its services (except for reimbursement of actual costs incurred); and represents low-income taxpayers in controversies with the Internal Revenue Service; or operates programs to inform individuals for whom English is a second language about their rights and responsibilities.").

${ }^{56}$ See The Community Tax Law Report, supra note 32. Two entire issues of the Community Tax Law Report were devoted to this topic: vol. 3, no. 1 (Winter 1998), and vol. 5, no. 2 (Fall/Winter 2001). The Community Tax Law Report was a remarkable newsletter designed to inform practitioners, and others, about issues facing low-income taxpayers. Nina recruited leading practitioners and scholars to write for the Report and usually built editions around themes. The two editions mentioned here focused on the issues facing immigrants and taxpayers for whom English was their second language.

Pitt Tax Review | ISSN 1932-1821 (print) 1932-1996 (online) DOI 10.5195/taxreview.2020.119 | http://taxreview.law.pitt.edu 
4. Created strategy of nationwide coverage. At the beginning of the grant process, LITCs received grants based on the strength of their applications without regard to location. ${ }^{57}$ This created areas that had strong coverage and areas without adequate coverage. ${ }^{58}$ In some states, no LITC existed and this created not only a lack of coverage but also a political liability for the program. She did demographic studies to determine the need for LITCs across the country and she worked to fill the gaps in approving new clinics. ${ }^{59}$ She also affirmatively reached out to try to find partners in underserved areas rather than simply waiting for someone to apply. ${ }^{60}$

5. Developed mission statement. LITCs as a group did not initially have a unifying mission statement. Because they are a diverse group with no unifying body, a mission statement for LITCs would probably never come without an outside push. That push came from Nina. Beginning with the 2011 grant cycle, TAS adopted a central mission statement for the LITC program. ${ }^{61}$ The mission statement changed slightly in 2017 and again in 2020, but it still highlights core tenets of representation, education, and advocacy.

\footnotetext{
${ }^{57}$ This statement reflects the personal observations of the author. I participated in the grant review process for the 2000 cycle as one of a group of IRS and Chief Counsel employees brought in from around the country. In that review process, we were not provided with guidance regarding location as a factor to consider in recommending that a clinic receive a grant.

${ }^{58}$ As an example I would cite the contrast between Philadelphia and New York City when I began my work as director of the LITC at Villanova Law School. In 2007, Villanova was the only LITC in Pennsylvania east of Pittsburgh. It also served southern New Jersey, where no LITC existed, and Delaware, where no clinic existed. By contrast, New York City had nine LITCs in 2007. In her quest to locate clinics in underserved areas, Nina affirmatively sought to locate a clinic in Scranton, which ultimately did not last, and also sought to create a clinic in Philadelphia at Philadelphia Legal Aid, a clinic in central Pennsylvania, a clinic in southern New Jersey, and a clinic in Delaware. She identified eastern Pennsylvania, southern New Jersey, and Delaware as underserved areas and affirmatively sought to fill gaps. This is just one example of the approach she took throughout the United States.

${ }^{59}$ See, e.g., I.R.S. Pub. No. 3319, Low Income Taxpayer Clinics: 2021 Grant Application Package and Guidelines, at 2 fig. 1 (2020) (telling applicants where the underserved areas of the country are located and depicting them on a map of the United States).

${ }^{60} \mathrm{I}$ observed her in this process and worked with TAS as it sought to convince partners in the greater Philadelphia area.

${ }^{61}$ See I.R.S. Pub. No. 3319, supra note 59, at 1 (explaining the three general goals of LITCs as providing representation, education, and advocacy for low-come or ESL taxpayers).
}

Pitt Tax Review | ISSN 1932-1821 (print) 1932-1996 (online)

DOI 10.5195/taxreview.2020.119 | http://taxreview.law.pitt.edu 
For those LITCs seeking grant funds, TAS requires that they report their progress on achieving this mission in their interim and yearend reports. The most recent version of the mission statement provides:

Low Income Taxpayer Clinics ensure the fairness and integrity of the tax system for taxpayers who are low income or speak English as a second language (ESL):

- By providing pro bono representation on their behalf in tax disputes with the IRS;

- By educating them about their rights and responsibilities as taxpayers; and

- By identifying and advocating for issues that impact low income taxpayers. ${ }^{62}$

6. Encouraged clinics to band together in discussion groups and assigned mentors. Some of the early clinics banded together for a monthly call to discuss common issues. Susan Morgenstern at the Legal Aid Society of Cleveland formed one of the early groups, which was centered in Ohio and primarily gathered together clinicians at legal aid organizations. Nina recognized the benefit of this type of group gathering to help integrate clinicians who otherwise operated in an isolated setting. Through the program office at TAS, which ran the grant, she encouraged the creation around the nation of these types of groups and she assigned mentors to new clinics to assist them in navigating the issues they would face.

\section{B. Pushed for Actions and Resources That Aided Clinics}

LITCs needed assistance in ways that might not have been readily apparent to individual clinics but which Nina saw from her position as the NTA. She engaged in discussions with other parts of the bureaucracy and with Congress to obtain beneficial rulings or funds that would allow the LITCs to grow. In fighting these battles behind the scenes, she pulled together statistics and information from across the federal government in order to effectively advocate for positions that would strengthen LITCs.

${ }^{62} I d$.

Pitt Tax Review | ISSN 1932-1821 (print) 1932-1996 (online) DOI 10.5195/taxreview.2020.119 | http://taxreview.law.pitt.edu 
1. Held off Treasury Inspector General for Tax Administration on oversight methods. The Tax Inspector General for Tax Administration (TIGTA) criticized TAS for its oversight of LITCs because TAS did not look at the cases worked by the LITCs to determine if the cases were properly handled. ${ }^{63}$ If TAS adopted the recommendation of TIGTA, a huge fight would have ensued between the LITCs and TAS. Nina recognized the legal issues raised by the TIGTA recommendation and pushed back hard against this recommendation. ${ }^{64}$ She argued that looking at individual case files by IRS employees was inappropriate and a breach of the confidentiality of the client information. To resolve this disagreement, she was actually able to cause the creation of a federal regulation on the issue which states: "The right of access under 2 CFR 200.336 shall not extend to client information held by attorneys or federally authorized tax practitioners under the Low Income Taxpayer Clinic program."

\begin{abstract}
${ }^{63}$ See Weinberger, supra note 3, at 1080-81; see also TREASURY INSPECTOR GEN. FOR TAX ADMIN., supra note 26 (explaining that financial information submitted by clinics to the IRS could not always be used to explain whether LITCS were properly using the granted funds); TREASURY INSPECTOR GEN. FOR TAX ADMIN., REF. NO. 2008-10-142, IMPROVED CONTROLS OVER GRANTS PROVIDED TO LOW INCOME TAXPAYER Clinics WOULD LOWER THE RISK OF THE INAPPROPRIATE USE OF FEDERAL GOVERNMENT FUNDS (2008), https://www.treasury.gov/tigta/auditreports/2008reports/200810142fr.html (proposing that the NTA and IRS develop and implement procedures for oversight of LITCs' use of grant funds); TREASURY INSPECTOR GeN. FOR TAX ADMIN., ReF. No. 2017-10-005, IMPROVEMENTS ARE NeEded in the TaXpayer AdVocate Service Process to Implement ReCommended Corrective ACTIONS 37-38 (2016) (explaining that TAS disagreed with TIGTA's findings pertaining to the procedural requirements enforced by the IRS if LITCS do not file both an interim and year-end report in a timely manner).

${ }^{64}$ In working this issue, Nina and the Chief Counsel attorneys representing her looked at the oversight that the Legal Services Corporation provided to the many organizations around the country to which it provided grant funding. Using this long-established government program as a model, she was able to argue successfully for a similar review process between TAS and the LITCs. An NTA less versed in poverty law might not have known to go looking for this parallel program as a source of resolving the issue raised by TIGTA. TIGTA's recommendation made good sense from a purely audit standpoint, but TIGTA auditors lacked the necessary perspective of the confidentiality issues presented by having IRS employee, albeit "independent" ones in TAS, looking at client records of client matters involving cases in litigation or administrative dispute with the very employer of the IRS employees going through the case files. In resolving this issue without involving the LITCs, Nina fixed a problem most LITCs did not even know existed but one that would have greatly influenced their program or their participation had she failed to avoid individual case review.
\end{abstract}

${ }^{65} 2$ C.F.R. $\S 1000.336$ (2014).

Pitt Tax Review | ISSN 1932-1821 (print) 1932-1996 (online)

DOI 10.5195/taxreview.2020.119 | http://taxreview.law.pitt.edu 
2. Reversed decision of Chief Counsel regarding use of matching funds from Legal Services Corporation. Matching funds provide the lifeblood of LITCs because the amount of the grant an LITC may receive is limited by the amount of matching funds raised. ${ }^{66}$ Related to the preceding topic in a tangential way, many LITCs, about half, now reside within organizations funded by the Legal Services Corporation. ${ }^{67}$ The organizations funded by the Legal Services Corporation do not receive all of their funding from that entity but do receive substantial funds that go toward the overall operation of the office. Chief Counsel wrote an advisory opinion stating that the LITCs receiving funds from the Legal Services Corporation could not use those funds to count toward the matching funds needed to obtain the grant under $\S 7526 .{ }^{68}$ Nina pushed back against this advisory opinion and persuaded Chief Counsel's office to reverse its decision.

This change in position allowed many legal services organizations to expand their LITC operations. Starting from no LITCs within legal services organizations at the time of the creation of the grant, now more LITCs exist within legal services organizations than any other type of LITC. The move of LITCs into legal services organizations fulfills a goal of working to reduce the civil justice gap that played a role in Nina's original decision to start CTLP. ${ }^{69}$

Having an LITC at a legal services organization provides many challenges and many benefits. The challenges are discussed in an article that I wrote for the management magazine for these

\footnotetext{
${ }^{66}$ I.R.C. § 7526(c)(5); see I.R.S. Pub. No. 3319, supra note 59, at 96.
}

${ }^{67}$ Legal Services Corporation is a nonprofit organization based in Washington, D.C., through which funding for legal services around the country runs. Fogg, supra note 18, at 38. As an independent entity, Legal Services Corporation keeps administration of the legal services program away from the executive branch. Id.

${ }^{68}$ Memorandum from Donald M. Suica, Chief, Pub. Conts. \& Tech. L. Branch, Gen. Legal Servs., Off. of Chief Couns., to Susan E. Gilbert, Acting Chief, Grant Admin., Wage \& Inv. Operating Div., Stakeholder P'ships, Educ. \& Commc'n (July 20, 2002) (on file with author).

${ }^{69}$ See Press Release, Am. Acad. Arts \& Sci., New Issue of Dadalus Takes on the Justice Gap Facing Poor and Low-Income Americans (Jan. 7, 2019), https://www.amacad.org/news/new-issuedaedalus-takes-justice-gap-facing-poor-and-low-income-americans (discussing the civil justice gap).

Pitt Tax Review | ISSN 1932-1821 (print) 1932-1996 (online) DOI 10.5195/taxreview.2020.119 | http://taxreview.law.pitt.edu 
organizations. ${ }^{70}$ The primary challenge centers on the employee running the LITC. That individual frequently has little or no tax background and has no one within the organization to teach them about tax issues. ${ }^{71}$ For some attorneys placed in this position, the amount of knowledge needed to manage a successful tax practice proves overwhelming. For others, it presents a surmountable challenge leading to a rich practice in which the attorney serves as a hub for many of the practice areas of the legal services organization. $^{72}$

Nina tried to assist the legal services attorneys directing tax clinics in a number of ways. She sought to have them assigned a mentor within the LITC community. She tried to provide training for these individuals at the annual LITC conferences and in other settings. The benefits of having an LITC within a legal services organization are far reaching and definitely worth all of the effort Nina made to reach out and embed LITCs within these centers of poverty law created at a time before tax received recognition as an integral part of that practice.

3. Obtained waiver from the Office of Management \& Budget (OMB) regarding the use of matching funds from volunteers. Similar to, but distinct from, the matching fund issue discussed above was the issue of obtaining a match for the time donated by volunteer attorneys and others. Many clinics struggle to obtain cash donations but can more easily obtain the donation of time. Depending on the value of that time, the LITC can obtain enough donated time to satisfy the matching fund requirement of $\S 7526$.

OMB placed limitations on the use of volunteer time to satisfy matching grants. The limitation impeded some clinics from obtaining the maximum amount of the $\S 7526$ match. By obtaining

${ }^{70}$ See T. Keith Fogg, Tax Issues Facing Clients of Legal Services, 28 MIE J. 1, 17 (2014).

${ }^{71}$ See Dave Pantos, A Successful LITC Program: An Interview With Jamie Andree, Managing Attorney Indiana Legal Services, 28 MIE J. 48, 49 (2014) (illustrating how having a lack of tax knowledge could present an initial challenge to the operator of an LITC).

${ }^{72}$ See id. at $48-49$ (illustrating how the LITC in this situation can serve as a tremendous asset to the clients of the legal services organization).

Pitt Tax Review | ISSN 1932-1821 (print) 1932-1996 (online) DOI 10.5195/taxreview.2020.119 | http://taxreview.law.pitt.edu 
a waiver from $O M B$, Nina changed the game for a large number of LITCs. ${ }^{73}$ As discussed below, Nina promoted the idea of pro bono service by tax lawyers and other tax professionals. So, she not only aided clinics by removing the barrier imposed by OMB but she also aided them by creating an atmosphere of volunteerism among tax professionals.

4. Raised the amount of grant funds through persistent discussions with Congress about the need for the increases. The original amount Congress budgeted for LITC grants was $\$ 6$ million. ${ }^{74}$ That amount was more than adequate for the number of clinics that existed in 1998 but quickly became inadequate. By 2001 , the number of clinic applications spread the $\$ 6$ million too thin and more money was needed for the grant to be effective. ${ }^{75} \mathrm{In}$ response to requests from clinicians, Congress increased the amount budgeted for grants to $\$ 7.5$ million in $2004 .{ }^{76}$ That was the

\footnotetext{
${ }^{73}$ The LITC program office submitted a request to OMB to deviate from the required calculation of donated time (not specific to LITCs, but rather across the federal government) - and the thrust of it was that there is already a statute, I.R.C. $\S 7430$, that provides the mechanism for calculating attorney time/rate for tax controversies. Under the OMB rules, the value of attorney time was vastly underestimated, resulting in a much lower matching rate than the $\S 7430$ rate. Among other things, TAS argued that the application of the OMB rate would discriminate against low-income taxpayers. Essentially, this argument was that the donation of time to low-income taxpayers would be less than the value of the time spent by tax practitioners for more well-heeled taxpayers. Ultimately, OMB agreed with the position taken by TAS, and that benefited the LITC programs relying on volunteer time to meet the match. For some programs, the additional value of their volunteer time resulted in a direct case grant to them under $\S 7526$ because of the match it allowed.

${ }^{74}$ TREASURY INSPECTOR GEN. FOR TAX ADMIN., supra note 26, at fig.1.

${ }^{75}$ Taxpayer Advocate Report and Low-Income Taxpayer Clinics, supra note 38. Those invited to testify were Nina Olson, the National Taxpayer Advocate; Leslie Book, Federal Tax Clinic, Villanova Law School; Alan H. Cohen, Low-Income Taxpayer Clinic, Ithaca College; Community Tax Aid, Inc., Jeffrey S. Gold; Community Tax Law Project, Timothy B. Heavener; Dixon R. Rich, Jr., Low-Income Taxpayer Clinic, University of Pittsburgh School of Law; and Janet Spragens, Federal Tax Clinic, Washington College of Law, American University; see also Leslie Book, Tax Clinics: Past the Tipping Point and to the Turning Point, 92 TAX NOTES 1089 (Aug. 20, 2001).

${ }^{76}$ A 2011 TIGTA report shows the increases in the budget for LITCs over the years up to that point. See TREASURy InSPECTOR GEN. FOR TAX AdMin., supra note 26. The TIGTA report shows that the budget for grants to LITCs was increased by Congress in 2004 ( $\$ 7.5$ million), 2006 (\$8 million), 2008 (\$8.6 million), 2009 (\$9.5 million). Id. Subsequent to the 2011 TIGTA report, Congress has continued to increase the budget. See I.R.S. Pub. No. 5066-A, supra note 28 (mentioning that the grants in 2012 and 2013 were approximately \$10 million); 1 NAT'L TAXPAYER ADVOCATE, ANNUAL REPORT TO CONGRESS (2014) (mentioning a grant of $\$ 10$ million in 2014); I.R.S News Release IR-15-61 (Mar. 27, 2015) (mentioning a grant of $\$ 10.25$ million in 2015); I.R.S. News Release IR-16-32 (Feb. 26, 2016)
}

Pitt Tax Review | ISSN 1932-1821 (print) 1932-1996 (online)

DOI 10.5195/taxreview.2020.119 | http://taxreview.law.pitt.edu 
first of several increases. ${ }^{77}$ These increases came at a time of economic recession for the country and severe cutbacks to the budget of the IRS. Nina not only argued for the increases but also for the amounts to be designated within the budgets to ensure that LITCs would receive the funds. Her ability to keep the grant funds coming and to increase them during this period is a significant testament to her ability to sell the LITC program to congressional budget leaders who were not buying much of what the IRS was selling during this period.

Her constant work to increase the amount of grant funds available to LITCs provided a very tangible benefit to LITCs that resulted from her leadership. Many clinicians owe their jobs to her efforts to obtain and increase this grant and, relatedly, many taxpayers owe their success in fighting the IRS to these increases. Because most LITCs run on a very tight budget, the increased grant money available provided critical funding support.

5. Created an annual book of statistics and accomplishments by LITCs. By requiring more information in the grant reports, she created a database of information about the LITCs that did not previously exist. She used this information, in part, to cause the creation of an annual data book showcasing the work of the LITCs. ${ }^{78}$ The book followed a pattern of her fundraising efforts dating back to her time at CTLP. She gave copies of the book to the local taxpayer advocates (LTAs) with the directive that they provide a copy to the congressional offices they visited so that these offices would be aware of the work of the LITCs and the benefit of

(mentioning a grant of $\$ 10.72$ million in 2016); LITC Program Office's Latest Report Details Tireless Work of Those Giving Voice to the Voiceless, TAXPAYER ADVOC. SERV.: NTA BloG (Dec. 8, 2017), https://taxpayeradvocate.irs.gov/news/nta-blog-LITC-Program-Office-Latest-Report-Details-TirelessWork-of-Those-Giving-Voice-to-the-Voiceless (mentioning a grant of approximately $\$ 11.8$ million in 2017); I.R.S. News Release IR-18-121 (May 16, 2018) (mentioning a grant of over \$11.8 million).

${ }^{77}$ See supra note 76.

${ }^{78}$ The data book is published as IRS Publication 5066. See, e.g., I.R.S. Pub. No. 5066-A, Low Income Taxpayer Clinics Program Report (2019).

Pitt Tax Review | ISSN 1932-1821 (print) 1932-1996 (online) DOI 10.5195/taxreview.2020.119 | http://taxreview.law.pitt.edu 
funding the grant. ${ }^{79}$ The books also became an effective tool for the LITCs themselves in their efforts to raise funds and convince tax practitioners to join their pro bono panels.

The first LITC data book was published in 2013, and the book has been published every year since. ${ }^{80}$ These books not only contain statistical data culled from the annual reports filed by the LITCs but also contain stories about taxpayers the LITCs have assisted in their struggles with the IRS. Because all congressional offices receive requests for assistance in dealing with the IRS from their constituents, the data books reinforce the benefit to the constituents of the existence of LITCs, thereby assisting in the raising of the grant funds available through $\S 7526$.

6. Sent Local Taxpayer Advocates to congressional offices to talk about LITCs. Each year in February, Nina brought all of the LTAs to Washington and had them go to Capitol Hill to meet with the congressional offices covered by their respective offices. ${ }^{81}$ Prior to sending the LTAs up to Capitol Hill, they spent a day in Washington with Nina and others in TAS to learn of the agenda for the year, which is primarily based on the annual report to Congress. Each year, promoting LITCs was on the agenda of the discussion

${ }^{79}$ Each year in February she brings the LTAs from all over the country and sends them to Congress to discuss her annual report and other topics. The LTAs also make visits to the congressional offices within their service area. See discussion in the next subsection.

${ }^{80}$ E.g., I.R.S. Pub. No. 5066-A, supra note 28.

${ }^{81}$ See I.R.M. 13.6.1.12.3 (Feb. 28, 2012). The Congressional Affairs Program (CAP) predated Nina's appointment as NTA, but changed during her tenure. Originally, the LTAs and the government liaisons in the local areas would come to Washington, D.C. in February and go up to the Hill together. The trips probably started following the first NTA report to Congress in 1999. Nina joined TAS in March 2001, but before she officially started she met with the LTAs in February 2001 at the CAP conference. There was some nervousness at the time, on the part of the IRS, that going together to the Hill was awkward. In 2002, in her first year officially running the conference, TAS split from legislative affairs in planning and making the visits. In that year, the visits became a pure TAS event, with the LTAs meeting with their congressional delegations and briefing them on the Hill. Before they went up to the Hill, they spent the day with the NTA and her staff who walked them through the issues in the annual report, and they could ask questions about how to present things. This briefing almost always included a discussion of LITCs. The system also involved reporting back to the NTA if there were issues raised by any members of Congress so that TAS could follow up on those issues. TAS used these trips to develop and maintain close relations with congressional offices, which became important when seeking support for additional funding for the LITC grants.

Pitt Tax Review | ISSN 1932-1821 (print) 1932-1996 (online)

DOI 10.5195/taxreview.2020.119 | http://taxreview.law.pitt.edu 
with the congressional offices, in addition to the discussion of the annual report.

Consistent with her ongoing effort to raise the amount of the grant and raise the profile of LITCs, she gave the LTAs talking points about LITCs, including providing each office with a copy of the LITC yearbook and a copy of the list of LITC phone numbers and addresses. Measuring the impact of this effort is difficult but the fact that the grant amount increased at the same time the IRS budget withered suggests that the strategy provided a significant benefit to LITCs.

7. Kept away restrictions on clinic practice. Section 7526 contains no restrictions on the types of clients that a clinic receiving the grant can represent. She was aware of the restrictions that Congress had imposed on organizations receiving funds through the Legal Services Corporation. ${ }^{82}$ To date, Congress has imposed no similar restrictions on LITCs, allowing them to represent all individuals with tax problems.

\section{Expanded Taxpayer Advocate Service Oversight of Low-Income Taxpayer Clinics}

Before she became the NTA, Nina ran a clinic for two and one-half years under the grant program. She had the opportunity to experience the effectiveness of the grant administration by the IRS in preparation for her role as NTA. When she arrived at the IRS, her office did not administer the grant, but after she got herself established within the IRS, she sought to move the administration of the grant funds from W\&I to TAS in order that she could more effectively manage the program. By engendering the move of oversight of the program to TAS, she obtained the ability to assist and to shape the overall LITC community.

1. Took over LITC grant review from the Wage \& Investment Division. When Congress passed $\S 7526$ in 1998 and created the grant program for LITCs, the IRS was undergoing a significant

8242 U.S.C. § 2996(f).

Pitt Tax Review | ISSN 1932-1821 (print) 1932-1996 (online) DOI 10.5195/taxreview.2020.119 | http://taxreview.law.pitt.edu 
change in structure ordered by the same legislation that created $\S 7526 .{ }^{83}$ The IRS did not reorganize until September $2000 .{ }^{84}$ Prior to the reorganization, the IRS had to administer the first year of the grant program. It did so by using Stakeholder Partnerships, Education, and Communication (SPEC) before the official standup of W\&I. ${ }^{85}$

After the reorganization, the IRS chose to place the LITC grant administration within the Wage \& Investment operating division. ${ }^{86}$ The IRS had not previously administered a grant program. ${ }^{87}$ TIGTA provided oversight for the administration of the LITC grant program as part of its overall oversight of the IRS. ${ }^{88}$ Of course, at the same time it passed $\S 7526$ creating the grant program, Congress also created the Taxpayer Advocate Service. ${ }^{89}$ The IRS chose to place the administration of the LITC grant in Wage \& Investment in large part because the taxpayers represented by LITCs would almost all fit the Wage \& Investment criteria.

At the time of the review of the initial grant, Nina Olson had not yet become the NTA. She became the NTA on March 1, 2001. ${ }^{90}$ After becoming the NTA, she did not immediately seek to bring

${ }^{83}$ See Internal Revenue Service Restructuring and Reform Act of 1998, tit. I, Pub. L. No. 105-206, 112 Stat. 685, 689-724 (1998).

${ }^{84}$ I.R.S. News Release IR-00-67 (Sept. 27, 2000).

${ }^{85}$ See id.

${ }^{86}$ TREASURY INSPECTOR GEN. FOR TAX ADMIN., supra note 26 (stating that prior to the transfer of administration and oversight of the LITC program to TAS in May 2003 that function was performed by the Wage and Investment Division).

${ }^{87}$ The other grant program it administers is the grant program for VITA. Congress established the VITA grant program in December 2007. I.R.S. Pub. No. 4883, Grant Programs Resource Guide for VITA Volunteer Income Tax Assistance \& TCE Tax Counseling for the Elderly 4-5 (2018).

${ }^{88}$ Office of Investigations (OI), TREASURY INSPECTOR GEN. FOR TAX ADMIN., https://www .treasury.gov/tigta/oi.shtml (last visited Jan. 4, 2019) ("The Treasury Inspector General for Tax Administration (TIGTA) was established ... to provide independent oversight of IRS activities.... TIGTA's oversight extends to the IRS, IRS Chief Counsel and the IRS Oversight Board.").

${ }^{89}$ Internal Revenue Service Restructuring and Reform Act of 1998, § 1102, Pub. L. No. 105-206, 112 Stat. 685, 698-702.

${ }^{90}$ I.R.S. News Release IR-01-6 (Jan. 12, 2001).

Pitt Tax Review | ISSN 1932-1821 (print) 1932-1996 (online) DOI 10.5195/taxreview.2020.119 | http://taxreview.law.pitt.edu 
the review of the LITC program into TAS, but soon thereafter she began having discussions with the director of W\&I and with the Commissioner about moving the administration of the LITC grant into TAS. W\&I administered the program with one or two employees. $^{91}$

In 2003, the administration of the LITC grant moved into TAS. ${ }^{92}$ The movement of the grant administration of the LITC program from W\&I to TAS resulted from a push by Nina, and it allowed her to shape the program during the remainder of her time as NTA.

2. Took over the process of authorizing student practice before the IRS. Each semester, clinics that use students, which include nonacademic clinics using student interns, must obtain authorization for those students to practice before the IRS. ${ }^{93}$ The process of obtaining the authorization from the Office of Professional Responsibility (OPR) was cumbersome. ${ }^{94}$ Nina brought the process into TAS after reaching an agreement with OPR. ${ }^{95}$ The process within TAS was streamlined, allowing clinics to obtain the authorization within a few days of the request. ${ }^{96}$

As a part of authorizing student practice, Nina listened to criticism of the rules that required that a student have completed a basic federal income tax class. ${ }^{97}$ That rule created a barrier to the use of

${ }^{91}$ This observation is based on discussion between author and LITC directors working at that time.

92 U.S. GOV'T ACCOUNTABILITY OfFICE, GAO-07-156, TAXPAyer AdVOCATE SERVICE: Caseload Has Grown and Taxpayers Report Being Satisfied, but Additional Measures of EFFICIENCY AND EFFECTIVENESS ARE NEEDED, app. V (2007); see also supra note 26.

${ }^{93}$ See I.R.S. Deleg. Order 25-18 (Aug. 19, 2019) (authorizing students working at LITCs to practice before the IRS under Circular 230, $§ 10.7$ (d)); see also I.R.S. Pub. No. 947, Practice Before the IRS and Power of Attorney 3, 5 (2018) (allowing students to practice under the supervision of an attorney or other authorized practitioner if the student is enrolled in a class). Bill Nelson suggested this change to Nina.

${ }^{94}$ I say this based on personal experience of working with OPR during the first several years I directed the clinic at Villanova Law School.

${ }^{95}$ See I.R.S. Deleg. Order 25-18, supra note 93.

${ }^{96}$ This statement also stems from personal experience. The process is now streamlined to allow a clinic to fax in the request and often receive the authorization letter the next day. Because enrollment in my clinic often shifts during the first week of classes, this speed and flexibility makes the authorization process much better than the process that previously existed.

${ }^{97}$ I argued for this and Nina caused the rule to change.

Pitt Tax Review | ISSN 1932-1821 (print) 1932-1996 (online) DOI 10.5195/taxreview.2020.119 | http://taxreview.law.pitt.edu 
students because most law schools do not offer the class in the first year. The course on basic income tax teaches almost nothing that students use in their clinic work. After discussion with the clinics, Nina acknowledged that the requirement did not protect clients or the students and eliminated the requirement, opening up more volunteers for clinics to use and particularly students volunteering in the summer after their first year of law school.

Another innovation in the student practice rules made possible after TAS took over the administration of this process involved the use of students who graduated and were awaiting bar results. Each year students exist in this posture who do not have a job lined up and are waiting for bar results in order to push for employment. Some of these students are willing to volunteer at clinics during the two or three months between the completion of the bar exam and the receipt of the bar results. Prior to a change in the rules regarding student authorization, these individuals did not qualify to practice before the IRS since they were no longer students but not yet lawyers. TAS heard the requests from clinics to allow these individuals to continue practicing as students until bar admission, and this opened up a source of volunteers for LITCs. ${ }^{98}$

3. Pushed for TAS employees to provide assistance as well as oversight. Nina created a grant office within TAS. ${ }^{99}$ Within that grant office, she created program analysts who each have responsibility for a number of clinics within a geographic area. These analysts not only review the clinics for grant compliance but regularly provide guidance and assistance to the clinics.

\section{Changed the Culture of Low-Income Taxpayer Advocacy}

Some of the discussion here relates to Nina's work before she became NTA and before TAS began administering the grant while some occurred or continued to occur after her office took over the grant. Dividing her impact on culture to periods before and after she led the LITCs as the NTA is impossible. Certainly, the formative ideas for much of her impact on culture

\footnotetext{
${ }^{98}$ See I.R.M. 13.1.23.4.6 (June 6, 2019).

${ }^{99}$ See I.R.C. § 7803(c)(2)(A)(i).
}

Pitt Tax Review | ISSN 1932-1821 (print) 1932-1996 (online) DOI 10.5195/taxreview.2020.119 | http://taxreview.law.pitt.edu 
occurred when she ran CTLP; however, when she became the NTA, her ideas, which were previously known only to a small number of people, were broadcast on a national level and became a mainstream part of tax news. By remaining in the position of NTA for almost two decades, she had time to build out her ideas in a way that someone passing through the position for a normal period of government service would not. Take for example her idea of a taxpayer bill of rights (TBOR). Though it had formed earlier, she first published it in her annual report in 2007 and almost a decade later Congress codified it. ${ }^{100}$ Still today, that idea remains in a formative stage with respect to how it will impact the system of taxation. ${ }^{101}$ TBOR represents just one example of an idea she brought to the table which changed or will change tax culture and especially that part of tax culture that impacts low-income taxpayers.

1. Created a model for issue advocacy. The role of issue advocacy by LITCs cannot be underestimated. Low-income taxpayers had no voice in regulatory and subregulatory pronouncements by the IRS prior to the creation of LITCs and the recognition by LITCs that engaging in issue advocacy was critical to their clients. Nina provided both a role model for this type of advocacy based on the work that she and Janet Spragens did leading up to the IRS Restructuring and Reform Act of 1998, her subsequent work with the ABA Tax Section, and her work as NTA.

Issue advocacy has become a big part of the work of the Pro Bono and Tax Clinic Committee of the ABA Tax Section. That committee, comprised primarily of clinicians, seeks to comment on almost any IRS regulation or subregulatory guidance that impacts low-income taxpayers. In addition to the work of the committee, some clinics or groups of clinics have also taken on the role of

${ }^{100}$ See T. Keith Fogg, Can the Taxpayer Bill of Rights Assist Your Clients?, 91 TEMPLE L. REv. 705, 706 (2019).

${ }^{101}$ See id. at 706-07 (2019); see also Alice G. Abreu \& Richard K. Greenstein, Embracing the TBOR, 157 TAX NOTES 1281 (2017).

Pitt Tax Review | ISSN 1932-1821 (print) 1932-1996 (online)

DOI 10.5195/taxreview.2020.119 | http://taxreview.law.pitt.edu 
commenters with respect to guidance issues and even legislative issues. ${ }^{102}$

Several of the issue areas in which LITCs regularly represent clients saw the creation of regulations before LITCs got in the game. The litigation regarding the $\S 6015(\mathrm{f})$ regulation limiting taxpayers to making certain innocent spouse relief claims within two years provides a good example of before and after. ${ }^{103}$ The regulation, initially promulgated in 2002, received no comments on the two-year rule and no comments from the LITC community. ${ }^{104}$

Having missed the opportunity to influence and explain to the IRS why this regulation inappropriately interpreted the statute, LITCs were forced to litigate to try to effect a change. ${ }^{105}$ Even though the LITCs won in the Tax Court with a precedential opinion striking down the regulation, they lost in three circuit courts of appeal before approximately fifty members of Congress (perhaps with an assist from Nina) wrote to the Commissioner expressing their concern about the regulation and causing the withdrawal of the regulation. ${ }^{106}$

${ }^{102}$ See T. Keith Fogg, An Access to Justice Milestone, A.B.A. SeCtion TAX’N NewSQuARTERLy, Spring 2013, at 10 (detailing some of the involvement of clinicians in the regulations regarding the innocent spouse provisions); T. Keith Fogg, Meeting Leads to Changes to Certain Practices in the Tax Court, A.B.A. Section TAX'N NewsQuarterly, Fall 2013, at 28 [hereinafter Fogg, Meeting Leads] (detailing changes to Tax Court procedures discussed in meeting between the Tax Court and clinicians). These are just two examples of a multitude of comments by clinicians to the IRS and the Tax Court. The Pro Bono and Tax Clinics Committee of the ABA Tax Section regularly makes comments on proposed regulations and other guidance issued by the IRS as well as on rule changes proposed by the Tax Court. Some LITCs, such as the tax clinic at Harvard Law School, also regularly make comments on proposals that might impact low-income taxpayers.

${ }^{103}$ See Andrew R. Roberson, Making a Difference in Pro Bono Tax Cases, 36 A.B.A. TAX TIMES, Winter 2017, at 25, 26 (discussing, among other things, the work of the LITCs in litigating to change the innocent spouse regulations and working thereafter to change the guidance).

${ }^{104}$ See Treas. Reg. § 1.6015-5(b)(1) (2002); Relief from Joint and Several Liability, 66 Fed. Reg. 3888 (proposed Jan. 17, 2001) (leading to the rule with the two-year limit).

${ }^{105}$ See Lantz v. Comm'r, 132 T.C. 131 (2009), rev'd, 607 F.3d 479 (7th Cir. 2010); Mannella v. Comm'r, 631 F.3d 115 (3d Cir. 2011); Jones v. Comm'r, 642 F.3d 459 (4th Cir. 2011).

${ }^{106}$ See I.R.S. Notice 2011-70, 2011-32 I.R.B. 135 (announcing the intention of Treasury and the IRS to withdraw the regulation).

Pitt Tax Review | ISSN 1932-1821 (print) 1932-1996 (online)

DOI 10.5195/taxreview.2020.119 | http://taxreview.law.pitt.edu 
When the IRS began anew to write regulations with respect to the innocent spouse provisions, the LITCs provided significant contributions to the IRS regarding how those regulations should look. ${ }^{107}$ This change in participation level with respect to the regulatory process played out with respect to the collection due process regulations and regulations regarding the earned income tax credit as well as other topic areas of importance to low-income taxpayers. Having not participated in the initial drafting of the regulations, LITCs became quite active in the past decade. ${ }^{108}$

2. Moved tax law under the poverty law umbrella. Before Nina, tax did not register with poverty lawyers as an area of practice. Through her writing, speaking, and actions in creating CTLP, she created a seismic shift in the perception of the importance of tax law to the practice of poverty law. Certainly, much of her initial work to push tax as a recognized area of poverty law came in her years with CTLP and culminated in the testimony of Nina and Janet Spragens before Congress in their effort to create the grant; however, she used the position of NTA to push this practice area and the recognition of this area as a significant area of practice. ${ }^{109}$

3. Made pro bono service by tax lawyers mainstream. If you go back to the beginning of Nina's story and rationale for creating CTLP, the story finds its roots in her dissatisfaction with the pro bono opportunities for tax lawyers available when she graduated from law school. ${ }^{110}$ She attended law school for the purpose of

${ }^{107}$ See Jamie Andree, Celebrating Valentine's Day with Comments on the Innocent Spouse Regulations, PROCEDURALlY TAXING (Feb. 14, 2014), https://procedurallytaxing.com/celebratingvalentines-day-with-comments-on-the-innocent-spouse-regulations/.

${ }^{108}$ See Government Submissions, A.B.A. TAX SECTION, https://www.americanbar.org/groups/ taxation/policy/ (last visited Nov. 23, 2020). The Pro Bono and Tax Clinic Committee and its predecessor, the Low-Income Taxpayer Committee, have become a major player in the submission of comments to the IRS regarding proposed regulations.

${ }^{109}$ See Pantos, supra note 71.

${ }^{110}$ Nina E. Olson, The Tax Section's Role as an Advocate for Equal Access to Justice: A Personal History, 68 TAX LAW. 427, 427 (2015); see also IRS Restructuring, supra note 16, at 329 (mentioning that Nina listed providing low-income Virginia residents with pro bono legal representation as the purpose of CTLP in her prepared statement).

Pitt Tax Review | ISSN 1932-1821 (print) 1932-1996 (online) DOI 10.5195/taxreview.2020.119 | http://taxreview.law.pitt.edu 
continuing and expanding her preexisting tax practice. She had no experience with landlord-tenant law, criminal law, consumer law, or other traditional areas of poverty law practice where pro bono opportunities existed. The lack of outlet for her to provide pro bono services as a tax lawyer led her to create CTLP. ${ }^{111}$

Because of her work in creating CTLP and promoting pro bono service by tax lawyers, it is now much more normal for a tax practitioner to give their time or their money to assist low-income taxpayers. ${ }^{12}$ Her credibility and her connection to the LITC community have helped with recruiting. This assistance goes hand in hand with the need to obtain matching funds for the grant under $\S 7526$. The culture of service Nina worked to create has now permeated the ABA Tax Section, which gives its only annual award in recognition of pro bono service and which has created a significant endowment to support public service to low-income taxpayers. ${ }^{113}$ You can trace the ideas for the award and the public service scholarships directly back to the culture that Nina created.

4. Personally connected with clinics. Nina knew how to connect with new clinics or struggling clinics to provide them with concrete ideas on how to form or how to improve. Her background as a clinician who went through all of the struggles made her advice and comments particularly valuable to members of the LITC community.

LITCs benefit significantly from having the person in charge of their grant funding come from their community. Because she started and built up a clinic, she knew exactly the struggles that new clinics face, and she worked to create a structure that supports and nourishes these clinics.

She built out the LITC program office from an office run by one person when W\&I administered the grant to an office of over

\footnotetext{
${ }^{111}$ Olson, supra note 110, at 427.

${ }^{112}$ See Fogg, supra note 18, at 53-57 (while the ABA Tax Section has been a part of low-income tax clinics from the beginning, the work of Nina Olson significantly heightened the profile of pro bono work within the ABA Tax Section).

${ }^{113}$ See Pro Bono Award, A.B.A., https://www.americanbar.org/groups/taxation/awards/probono (last visited Jan. 4, 2020).
}

Pitt Tax Review | ISSN 1932-1821 (print) 1932-1996 (online)

DOI 10.5195/taxreview.2020.119 | http://taxreview.law.pitt.edu 
twenty individuals. Each clinic has an analyst assigned to assist them. For some clinics with strong foundations the analysts provide little support, but for new or struggling clinics these individuals can assist in identifying needed support.

Nina also designed programming to specifically assist new clinics and new clinicians. She met with many of these individuals and sought to assist them to get off the ground.

5. Served as a motivator. She served as a motivator and cheerleader for LITCs every year during her speech at the LITC conference and during her office visits. She is also a motivator and a publicist for LITCs in almost all of her speeches because of her constant championing of the issues of low-income taxpayers.

This is another benefit to LITCs that is difficult to quantify but that had benefits to the LITC community. Nina has a compelling story about starting CTLP and about her efforts to find funding for it to allow it to continue and to grow. She told that story in many settings and used it to inspire LITC directors to take the necessary effort to ensure the success of their clinics. She not only had stories from her days at CTLP but she also had stories related to her many trips to the Hill to testify and stories of her battles within and without the IRS to promote issues of importance to low-income taxpayers. She had won so many things in her career as a clinician and as NTA that she provided an inspiration on many levels.

6. Included LITC directors in TAS training programs. Nina included LITC directors in training of TAS employees, bringing home to the IRS employees the importance of different advocacy styles. ${ }^{114}$

Unlike most segments of the IRS, she affirmatively sought speakers from the LITCs for training programs for her employees. Doing this allowed the employees to better see and understand the issues facing LITCs and the taxpayers they represented. ${ }^{115}$ It also allowed the LITC employees who engaged in the trainings to

\footnotetext{
114 NAT'L TAXPayer AdVOCATE, 2017 ANNUAL REPORT to CONGRESS, at 90 (2017).

${ }^{115} I d$.
}

Pitt Tax Review | ISSN 1932-1821 (print) 1932-1996 (online) DOI 10.5195/taxreview.2020.119 | http://taxreview.law.pitt.edu 
obtain a better idea of the issues facing the TAS employees. The use of LITC directors in TAS training provided real benefits to both sides.

7. Recruited LITC directors to work at TAS. Nina affirmatively sought to recruit LITC directors to the position of LTA in offices around the country and to the position of program manager overseeing the LITC grant. In doing so, she brought to these positions individuals who understood the work of LITCs and who could better assist LITCs in their effort to represent taxpayers.

Each clinic is nominally overseen by their local LTA, in addition to an analyst from the LITC program office. ${ }^{116}$ Having someone in the LTA position who understands the issues facing an LITC gives that LITC a real benefit both by having a great resource for mentoring and by having a sympathetic ear for cases referred for assistance. By making a point of seeking LITC directors to serve in the LTA positions in some offices around the country, Nina also provided colleagues for the LTAs who do not come from an LITC background. Infusing into the group a cadre of clinicians allows this cadre to let the other LTAs know about the issues arising from the LITC community which has a direct benefit to LITCs.

Having Nina, with her background in the LITC community, oversee the grant fostered better communication between the grantor and the grantees. Her knowledge of LITCs enabled TAS to better evaluate the effective clinics and the ineffective ones.

8. Made the LITC program director a direct report. She made the director of the LITC program office a direct report to her, elevating the status of the LITC program. ${ }^{117}$

How the government is organized and who reports to whom in the government makes a strong statement regarding the importance of a position. By elevating the director of the LITC program office to a position directly reporting to her, Nina signaled the importance of LITCs to her role as NTA. The organizational change let those inside and outside of the IRS know that LITCs played an important

${ }^{116}$ See I.R.M. 1.1.8.1.1.1 (June 9, 2005).

${ }^{117} \mathrm{Id}$. at exhibit 1.1.8-1.

Pitt Tax Review | ISSN 1932-1821 (print) 1932-1996 (online) DOI 10.5195/taxreview.2020.119 | http://taxreview.law.pitt.edu 
role in advocating for an important segment of the taxpayer population.

9. Set up a meeting between the Commissioner and representatives of LITCs. Nina did not stand by and observe but jumped in and made things happen. She did this in many ways. One strong example of the way she got LITCs involved in important policy making within the IRS occurred when she helped to engineer a meeting between several LITC directors and the IRS Commissioner in the immediate aftermath of the IRS pulling back on its regulation under $\S 6015(\mathrm{f})$ creating a two-year rule for requesting certain innocent spouse relief. ${ }^{118}$

Her office organized the meeting so that the Commissioner could hear directly from those representing innocent spouses how important the $\S 6015(\mathrm{f})$ issue was to representing these individuals and obtaining a fair result. ${ }^{119}$ The access provided to the LITC directors let them tell their stories about clients and why two years after the first collection activity was insufficient as a cut-off point for making the innocent spouse request. Without her intervention, the LITC directors would not have had this access to the Commissioner on an issue of critical importance.

\section{E. Connected LITCs to the Tax Court}

When Nina began CTLP, she almost immediately began to show up at Tax Court calendars and to take on Tax Court cases of low-income taxpayers. ${ }^{120}$ While this may sound normal today, it was not the norm of many LITCs. When she took over the administration of the grant and began the process of shaping LITCs to perform certain types of work and certain quantities of work, she noticed that most LITCs were reluctant to represent taxpayers in litigation. This reluctance stemmed, in part, from the fact that a high percentage of clinicians did not come from a tax background and did

\footnotetext{
${ }^{118}$ Roberson, supra note 103.

${ }^{119} I d$.

${ }^{120}$ See Olson, supra note 110 , at $427-28$.
}

Pitt Tax Review | ISSN 1932-1821 (print) 1932-1996 (online) DOI 10.5195/taxreview.2020.119 | http://taxreview.law.pitt.edu 
not feel comfortable going into Tax Court. She worked hard not only to press them to pick up this work but also to make them comfortable in doing so.

She fostered a strong relationship between LITCs and the Tax Court by, among other things, including Tax Court judges in the Annual LITC Conference and encouraging LITCs to attend the Tax Court Conference that is held every few years.

In 1996 she entered into an agreement between CTLP and the Tax Court that allowed information about CTLP to be disseminated to taxpayers in Virginia. ${ }^{121}$ This was the first agreement between the court and a nonacademic clinic ${ }^{122}$ and came only after a few years of negotiation. She recognized early the power of partnering with the Tax Court to reach clients and to assist them at a critical point in their tax journey.

As NTA, Nina worked to foster the relationship between the court and the LITCs. At the 2006 annual LITC conference, she put on the program a discussion of how to handle a Tax Court case. ${ }^{123}$ At that time there were 150 clinics ${ }^{124}$ however, only a small number of those clinics accepted clients for Tax Court representation. Through the program she sought to convince the LITC directors that they could and should handle client cases in Tax Court. ${ }^{125}$ She followed up the discussion with changes to Publication 3319, which asked if a clinic had created a Tax Court participation agreement and used the answer to grade the clinic when determining the amount of grant award it should receive. ${ }^{126}$

${ }^{121}$ See id. at 428. The author observed a copy of the agreement in the files of CTLP.
${ }^{122} \mathrm{Id}$.
${ }^{123} \mathrm{See}$ I.R.S. Pub. No. 5066, Low Income Taxpayer Clinics Program Report 3, 12 (2014).
${ }^{124} \mathrm{Id}$.
${ }^{125}$ I was on the panel that discussed these issues together with Chief Special Trial Judge Panuthos, Professor Les Book from Villanova, and Nina Olson. At the time, I was a Senior Trial Attorney with Chief Counsel's Office in Richmond, Virginia, and rapidly approaching retirement from the government. While I believe the panel had the desired effect on some of the participants, and the number of Tax Court agreements would shoot up following the presentation, my participation in the panel had the direct effect of me becoming the director of the LITC at Villanova and following Les Book in that position. So, Nina's push for Tax Court participation had a profound impact on my career trajectory, if nothing else.

${ }^{126}$ See I.R.S. Pub. No. 3319, supra note 59, at 121; see also supra notes 47, 48, 58, 60.

Pitt Tax Review | ISSN 1932-1821 (print) 1932-1996 (online)

DOI 10.5195/taxreview.2020.119 | http://taxreview.law.pitt.edu 
In addition to the specific panel during the 2006 conference designed to convince clinics to begin Tax Court representation for their clients, Nina began inviting members of the court each year to speak to the LITCs at the annual conference. ${ }^{127}$ The relationship between the LITCs and the Tax Court was further fostered by the creation of the annual dinner at the Tax Court, which takes places during the LITC conference. ${ }^{128}$ The relationship between the LITCs and the court has grown over the years so that now almost all clinics have an agreement with the court to represent clients in their area at calendar call and through referral.

The Pro Bono and Tax Clinics Committee of the ABA Tax Section picked up on the work begun by the NTA to reach out to clinics and local bar associations to ensure coverage at all calendar calls and to ensure that in each of the seventy-four locations in which the Tax Court sits, one clinic or bar association had an agreement with the court that allowed the court to advise pro se litigants of the opportunity for representation. ${ }^{129}$ The work that the NTA began to marry the LITCs with the Tax Court to provide representation for pro se individuals who found themselves in litigation has become a

${ }^{127}$ See, e.g., William Schmidt, Episode 77: LITC Grantee Conference-December 2019 Followup, TAX JUST. WARRIORS (Dec. 20, 2019), https://player.fm/series/tax-justice-warriors/episode-77-litcgrantee-conference-december-2019-followup (mentioning a session at the 2019 LITC Conference where LITC directors were able to talk with judges of the Tax Court directly). Prior agendas of the annual LITC meeting are available in the LITC toolkit, a password protected site available to the clinics.

${ }^{128}$ Financial Services and General Government Appropriations for 2013: Hearings Before a Subcomm. on Fin. Servs. and Gen. Gov't Appropriations of H. Comm. on Appropriations, 112th Cong. 1952 (2012) (Tax Court budget justification by Chief Judge John O. Colvin). The dinner is not solely for LITCs, but its timing allows LITC directors to attend without difficulty. The court invites all LITC directors whose clinics have signed a participation agreement with the Tax Court. In addition, it invites numerous members of the Office of Chief Counsel and IRS as well as some tax practitioners not affiliated with LITCs. In addition to the dinner, the court convenes the group in the ceremonial courtroom for a program related to Tax Court practice and for a time when the judges can provide information about the court to those present. The event not only serves to connect LITC practitioners with the judges of the court, similar to a once-a-year Inn of Court, but also provides LITC practitioners with the physical space of the court.

${ }^{129}$ See Clinics and Pro Bono Programs, U.S. TAX CT., https://www.ustaxcourt.gov/clinics.html, for a discussion of the requirements for entering into an agreement with the court to provide representation at calendar call or to be placed in the stuffer notice sent to pro se litigants regarding the opportunity for representation). See also Andrew R. Roberson, The Calendar Call, A.B.A. SECTION TAX'N NEWSQUARTERLY, Winter 2014, at 13,13-15 (recounting Andy Roberson's experience handling a calendar call); T. Keith Fogg, A Calendar Call Staffing Success Story, A.B.A. SECTION TAX'N NEWSQUARTERLY, Winter 2014, at 13; Fogg, supra note 102.

Pitt Tax Review | ISSN 1932-1821 (print) 1932-1996 (online) DOI 10.5195/taxreview.2020.119 | http://taxreview.law.pitt.edu 
significant program that benefits the individual taxpayers, the court, and the Office of Chief Counsel by reducing the number of trials necessary and reducing the time of the trials that do take place. ${ }^{130}$

Nina also assisted in setting up and participated in a historic meeting between representatives of the LITC community and the Tax Court to discuss issues involving low-income taxpayers and how the Tax Court might think about addressing those issues. ${ }^{131}$

\section{F. Created Research Office That Provided Empirical Data to Support LITC Positions}

Nina created, within TAS, an office that could use available data to support or to identify issues of importance to LITCs (and to taxpayers generally.) ${ }^{132}$ She saw the benefit of using data to make decisions rather than just relying on arguments of what she or others might think was right. Although the research office did not work for the LITCs and its studies did not always have an impact on low-income taxpayers, the research office did provide a basis for some of the controversial decisions that she made. ${ }^{133}$ Without the research office, she would have had a more difficult time with some of the arguments she made personally or she allowed others to make using information from the research office. ${ }^{134}$

\section{CONCLUSION}

As NTA, Nina Olson built a strong LITC community. Under her leadership as the grant administrator, the community grew somewhat in the number of existing clinics but, more importantly, grew as a real voice for

\footnotetext{
${ }^{130}$ This statement has no empirical support but anecdotal evidence and discussions with the members of the court and Chief Counsel's Office suggests that the statement is correct.

${ }^{131}$ Fogg, Meeting Leads, supra note 102, at 28.

132 See Research Studies, TAXPAYER ADVOC. SERV., https://taxpayeradvocate.irs.gov/reports/ research-studies (last visited Jan. 4, 2020). The office is called TAS Research and Analysis, and it is mentioned in the website above. The NTA first mentioned a "TAS Office of Research" in her 2007 annual report. See 2 NAT'L TAXPAYER ADVOC., 2007 ANNUAL REPORT TO CONGRESS (2007).

133 See, e.g., 1 NAT'L TAXPAYer AdVOC., ANNUAl RePORT to CONGRESS 2018, at xi (2018) (citing a 2015 TAS research study to support the argument that taxpayer harm is being exacerbated by a lack of proper resources).

${ }^{134}$ See generally id.
}

Pitt Tax Review | ISSN 1932-1821 (print) 1932-1996 (online) DOI 10.5195/taxreview.2020.119 | http://taxreview.law.pitt.edu 
low-income taxpayers by expanding significantly the number of clients represented, the number of comment projects undertaken, and the representation of pro se Tax Court petitioners. Because she was a leader among LITCs before becoming the person in charge of the grant funds and because she had strong visions for how LITCs should operate individually and as a unit, Nina used her position as NTA to mold LITCs into a model much different than the one that existed before she became NTA. She did not just tell LITCs what to do but she also used her voice with the national tax press, within the IRS, and on Capitol Hill to ensure the success of the clinic program. It's hard to imagine that LITCs could have had a more effective voice leading their charge.

Pitt Tax Review | ISSN 1932-1821 (print) 1932-1996 (online) DOI 10.5195/taxreview.2020.119 | http://taxreview.law.pitt.edu 


\section{2 | Pittsburgh Tax Review | Vol. 182020}

\section{APPENDIX A}

\section{LITC GRANT REPORTING REQUIREMENTS OVER TIME}

PUB. 3319 FOR 2002

I.R.S. Pub. No. 3319, Low-Income Taxpayer Clinics 2002 Grant Application Package and Guidelines 3-10 (2001).

\section{LITC Program Introduction and Requirements}

Summary:

IRC $\S 7526$ authorizes the IRS to award matching grants of up to $\$ 100,000$ annually.

To be eligible for the LITC program, organizations must:

1. "Be a clinic that represents and/or refers low-income taxpayers in controversies with the IRS and/or operates programs to inform individuals for whom English is a second language about their tax rights and responsibilities." (p. 3)

2. "Be a clinic that supports qualifying activities that it conducts within a broader spectrum of activity, i.e., the operation of a 'clinic within a clinic' does not disqualify an applicant from eligibility for a LITC grant award." (p. 4)

3. "Not charge more than a nominal fee for clinic services (except for reimbursement of actual costs incurred). An additional fee may be charged for subsequent issues that arise after initial assistance." (p. 4)

Additional eligibility requirements include:

- Taxpayer income ceiling of $250 \%$ of federal poverty level for at least $90 \%$ of those represented. (p. 4-5)

- Amount in controversy ceiling of $\$ 50,000$ for any taxable year [generally]. (p. 4-5)

- Dollar-for-dollar matching funds for all LITC grants received. (p. 6)

Administrative requirements include:

- Grant award administrative requirements are "set forth in OMB and Treasury Circulars." (p. 7)

- "Programs involving use of federal funds are governed by a wide variety of federal laws, federal regulations, Executive Orders of the President, circulars and directives from the Office of Management and Budget and other Federal agencies." (p. 7)

Pitt Tax Review | ISSN 1932-1821 (print) 1932-1996 (online) DOI 10.5195/taxreview.2020.119 | http://taxreview.law.pitt.edu 
- Pursuant to the "“common rule' on non-procurement, debarment and suspension adopted by Department of Treasury at 31 CFR, Part 19 , Subpart F," the organization must certify that it is "not presently debarred or suspended from covered transactions by any Federal agency." (p. 8)

- $\quad$ Additional drug-free workplace certifications. (p. 8)

Grant Agreement

- An LITC Grant Agreement "includes functions and duties to be performed by the LITC grantee, geographic area of clinic services, as specified in proposed program plan, maximum amount of grant award, type of services to be performed by clinic, grant period, additional requirements specified in the application package and other pertinent information." (p. 8)

- The Agreements "may be awarded for up to three years periods of performance." (p. 8)

Civil Rights Reporting Requirements

- $\quad$ LITC grant applicants are subject to civil rights reporting requirements. (p. 8-10)

\section{Completion and Submission of LITC Application Package}

Summary:

Application Contents:

- Background information: an organization's qualifications, experience in dealing with low-income taxpayers, ability to utilize funds, management experience, etc. (p. 10)

- Program plan: goals, procedures, actions, etc.; if more than one type of assistance (representation, referral, or ESL) is requested, a program plan is needed for each type. (p. 10-12)

- Budget/financial information: budget narrative in conjunction with Standard Form 424A. (p. 12)

\section{Selection and Award}

Summary:

After eligibility screening (p. 14), the organizations are evaluated as follows:

- Technical evaluation: program quality, experience, number of lowincome taxpayers in the area. (p. 14-15)

- $\quad$ Cost. (p. 15)

Pitt Tax Review | ISSN 1932-1821 (print) 1932-1996 (online) DOI 10.5195/taxreview.2020.119 | http://taxreview.law.pitt.edu 


\section{4 | Pittsburgh Tax Review | Vol. 182020}

- Other considerations: existence of other LITCs in the area, other funding sources, etc. (p. 15)

\section{LITC Grantee Responsibilities}

Summary:

LITCs must:

- Designate a program director. (p. 18-19)

- Have managers that provide administrative support-providing training, monitoring compliance of program participants, maintaining records, etc. (p. 19)

- $\quad$ Keep taxpayer information confidential. (p. 19)

- Notify national LITC office and local SPEC representative of location, days, and hours of operation. (p. 19)

- Create, print, and distribute promotional and educational materials. (p. 19)

- "Publicize" the program. (p. 19)

- Monitor the quality of the service provided. (p. 20)

- Refer declined cases only to other pro bono organizations or state/local bar referral services. (p. 20)

- Not allow anyone associated with the clinic to charge for representation in a case declined by the clinic. (p. 20)

\section{LITC Reporting Requirements}

Summary:

Interim Reports:

- $\quad$ Financial narrative/report required. (p. 20)

- Program narrative required, including a description of:

o Strategy for "monitoring and evaluating program results";

o How the organization "define[s] and measure[s] its success";

o "[P] rogress made in implementing the LITC program";

o "Publicity methods";

o "The status of proposed goals and objectives";

o Impediments to meeting goals;

o Types of tax issues "in controversy," number of cases completed, number of outreaches, presentation topics, ESL educational information numbers, etc.; and

o For organizations that do tax return preparation, statistics on the number of ESL and non-ESL returns prepared/taxpayers assisted. (p. 20-21)

Pitt Tax Review | ISSN 1932-1821 (print) 1932-1996 (online) DOI 10.5195/taxreview.2020.119 | http://taxreview.law.pitt.edu 
Annual Reports:

- Financial narrative/report required with:

o Actual LITC expenses for the year;

o "Source, date, availability, and amount of matching funds"; and

o "Itemization and explanation of actual program costs for all expenses." (p. 21)

- $\quad$ Program narrative required, including a description of:

o Strategy for "monitoring and evaluating program results" and the "overall approach" to the LITC program;

o Methods "used to identify students, faculty, instructors, and program administrators"

o Training "provided for students and other program participants";

o Program publicity that was provided;

o For programs working with ESL taxpayers, additional information about ESL education and how many ESL taxpayers were reached/assisted;

o "How students and other program participants provided highquality representation";

o Process for maintaining client confidentiality;

o The number of taxpayers (including ESL) represented/assisted, broken out into several categories such as "[t]he number of taxpayers referred by the clinic to a qualified representative";

o If a taxpayer represented or assisted by the organization has income that exceeds "the amount specified in IRC §7463," the organization must explain the surrounding circumstances;

o "[T]he qualified representatives to whom taxpayers were referred";

o Internal methods for ensuring the clinic is following grant guidelines;

o Any fees charged by the clinic for representation;

o "[T]he type of assistance given by telephone";

o Clinics must include copies of the student certification letters;

o Any other activities of the clinic that further the IRS mission and are not mentioned elsewhere in the narrative; and

o Any recommendations for the LITC program. (p. 21-23)

Pitt Tax Review | ISSN 1932-1821 (print) 1932-1996 (online) DOI 10.5195/taxreview.2020.119 | http://taxreview.law.pitt.edu 


\section{6 | Pittsburgh Tax Review | Vol. 182020}

\section{LITC Training Conference}

Summary:

Applicants must "budget for two persons to attend a three-day technical assistance workshop."

PUB. 3319 FOR 2003

I.R.S. Pub. No. 3319, Low-Income Taxpayer Clinics 2003 Grant Application Package and Guidelines (2002).

New Operational Requirements

- Program plan-applicants must now describe plans for organizational/name changes.

New Reporting Requirements

- Year-end report, program narrative-organizations are now required to report the number of outreach/educational programs conducted. In addition, organizations must now report the number of tax returns filed electronically and the total number of controversy cases handled.

PUB. 3319 FOR 2004

I.R.S. Pub. No. 3319, Low-Income Taxpayer Clinic 2004 Grant Application Package and Guidelines (2003).

New Operational Requirements:

- LITC Program Standards-LITCs will now be held to the following "operating and ethical standards":

o Each clinic must designate one representative "to serve on an LITC substantive issue committee." (p. 7-8)

o Standards of operation - each clinic must:

- Have a qualified tax expert and a qualified business administrator on staff;

- Have proper internal controls with respect to safeguarding assets, compliance, etc.;

- $\quad$ Publicize services to target audience;

- $\quad$ Provide mentoring services to staff/volunteers;

- Network with other community organizations;

- Maintain library of current tax materials;

- Ensure staff has quality training; must attend conferences; and

- $\quad$ Ensure the volunteers are qualified. (p. 8)

Pitt Tax Review | ISSN 1932-1821 (print) 1932-1996 (online)

DOI 10.5195/taxreview.2020.119 | http://taxreview.law.pitt.edu 
- Two new responsibilities - organizations must:

- "[N]otify the LITC Program Office of developments that have a significant impact on the award-supported activities." (p. 24)

- $\quad$ Notify the LITC Program Office once it has been determined that the organization will not use all of the awarded funds.

New Reporting Requirements:

- Interim Reports, Program Narrative

o The section about reporting on efforts to publicize the clinic has been refined. Clinics are now required to report the number of individuals reached via marketing in addition to examples and numbers of materials distributed.

- Annual Reports, Program Narrative

o Generally speaking, the organization of this section has changed.

o Clinics no longer required to describe methods used for identifying students, faculty, etc. in this section.

o The section that requires description of "how students and other program participants provided high-quality representation" has been greatly expanded. Clinics are now required to "[d]escribe and provide examples of" review procedures, "information provided to ESL taxpayers," training provided to LITC employees/volunteers, "types of controversies handled by the LITC," how the LITC program was publicized, and referral mechanisms. (p. 29-30)

- On-site visitations

o This new section stipulates that the LITC Program Office will "periodically perform on-site assistance visits to selected clinics." The visits "may include reviews of intake procedures, referral record keeping systems, communication and publicity plan, demographics/population information, case statistics and analysis." (p. 33)

\section{New Section: LITC Program Office Responsibilities}

This new section stipulates that the LITC Program Office will help LITCs in the following ways:

- $\quad$ Furthering IRS understanding of LITC program;

- Helping place clinic materials in IRS Offices;

- Identifying helpful liaisons within the IRS; 
- "Maintaining a publication listing LITCs"; (p. 33)

- Making the existence of LITCs known to the public;

- Helping LITC marketing efforts;

- Answering the questions of LITC applicants;

- Furnishing information regarding the student certification process;

- Coordinating meetings between LITC and IRS representatives;

- Coordinating and executing on-site visits;

- $\quad$ Providing technical assistance and guidance to LITCs with respect to operating their programs;

- Coordinating LITC Program grant application reviews;

- "Coordinating Taxpayer Advocate Service Issue Committees"; (p. 33) and

- Providing information about obtaining tax forms, IRS publications, etc.

PUB. 3319 FOR 2005

I.R.S. Pub. No. 3319, Low-Income Taxpayer Clinic 2005 Grant Application Package and Guidelines (2004).

Nina's program goals for this year are the following:

- Each state must have at least one LITC program.

- Each state should have controversy representation and ESL outreach/education.

- $\quad$ LITC programs must show they are in an area with an adequate population in need of the services.

New Operational Requirements:

- LITC Program Standards-LITC standards of operation now include having "adequate referral systems controls" (p. 9)

PUB. 3319 FOR 2006

I.R.S. Pub. No. 3319, Low-Income Taxpayer Clinic 2006 Grant Application Package and Guidelines (2005).

There is a new form that needs to be submitted with interim and annual reports that will help with tracking the number of cases worked during year. There are also fewer redundant information requests between interim and annual reports. Finally, the client confidentiality requirement has been clarified.

Pitt Tax Review | ISSN 1932-1821 (print) 1932-1996 (online) DOI 10.5195/taxreview.2020.119 | http://taxreview.law.pitt.edu 
New Operational Requirements

- Determination of Program Performance-The application section was reworked a bit. The old "Program Plan" section was split in two. The "new" section requires applicants to provide the following information:

o Steps to ensure compliance with program rules;

o Matching funds;

o Geographic area to be served;

o Dates, days, hours of clinic operation;

o Cost-allocation and accounting procedures;

o Method for "allocating allowable expenses and matching funds between qualifying and nonqualifying activities"; (p. 16)

o Audit/control plans;

o Publicity plans;

o Plans to maintain client confidentiality;

o Strategy for monitoring program results; and

o Plans for name/organizational changes.

- Program Office Evaluation-After the technical evaluation, the LITC Program Office will now perform a secondary review.

- $\quad$ LITC Contact Information-LITCs now required to update their contact information with the LITC Program Office twice per year.

- Confidentiality-There is now more specific guidance regarding client confidentiality. In particular, the revised section outlines the circumstances under which client tax return information can and cannot be disclosed.

New Reporting Requirements:

- Interim Reports, Program Narrative-This section has been reworked a bit.

o LITCs now required to submit two completed forms (Supplemental Issue Form \& Interim Report Form).

o Tax return preparation numbers are no longer listed as a separate reporting requirement.

- Annual Reports, Program Narrative-This section has been reworked a bit.

o Opening paragraph of this section now specifies that the narrative must include explanations of why established goals were not met.

Pitt Tax Review | ISSN 1932-1821 (print) 1932-1996 (online)

DOI 10.5195/taxreview.2020.119 | http://taxreview.law.pitt.edu 
o LITCs must now submit Annual Report Form.

o LITCs must now describe the types of controversies handled, including processes for assignment, procedures for when a case exceeds an individual's skill level, mentoring activities, and monitoring system for quality.

o Representation/referral numbers are no longer listed as a separate reporting requirement.

PUB. 3319 FOR 2007

I.R.S. Pub. No. 3319, Low-Income Taxpayer Clinic 2007 Grant Application Package and Guidelines (2006).

NOTE: This version had a macro organization overhaul as compared to the previous version. Below I have highlighted only substantive/content-oriented changes (as opposed to macro organizational changes).

Nina pointed out three improvements made in response to a TIGTA audit: (1) clarification of standards and reorganization of the publication;

(2) emphasis on face-to-face contact "while recognizing the value of" written materials/advertisements as well; and (3) addition of Tax Information Authorization Form.

New Operational Requirements:

- Standards of Operation-This version of the form has the following changes:

o Having a clinic director with management responsibility is now a standard of operation.

o Clinics are now urged to include "substantive tax information" in "indirect outreach efforts." (p. 13)

o The "Referral Services" section has been expanded/clarified.

o New subsection: assurance of client confidentiality.

o New subsection: workgroup service.

o New subsection: tax compliance.

- The "Program Management" section no longer stipulates that a clinic needs a director (this is now in the Standards of Operation section). Furthermore, there is no longer a "Confidentiality" subsection here (this is also now in the Standards of Operation section).

New Reporting Requirements:

- Reporting Requirements, Interim and Annual Financial ReportsThe form now explicitly requests "[a] complete financial narrative,

Pitt Tax Review | ISSN 1932-1821 (print) 1932-1996 (online) DOI 10.5195/taxreview.2020.119 | http://taxreview.law.pitt.edu 
describing how grant funds were expended for the period" in both the Interim and Annual reports. (p. 20)

- $\quad$ Reporting Requirements, Annual Program Narrative:

o The form now requests an explanation of whether goals were met and an attached copy of the Supplemental Issue Form.

o The form no longer asks for recommendations for improvement of the program.

- Background Information-Applicants must now state whether they are "in compliance with federal tax responsibilities." (p. 27)

- Determination of Program Performance-Applicants must now explicitly describe their ability to meet each of the Standards of Clinic Operation in this section.

- Evaluation Process-There is a new component of the review process: "All applicants will also undergo a review of the organization's federal tax compliance status." (p. 35)

PUB. 3319 FOR 2008

I.R.S. Pub. No. 3319, Low-Income Taxpayer Clinic 2008 Grant Application Package and Guidelines (2007).

New Operational Requirements:

- All clinics must develop and utilize a written application or description for volunteer positions to ensure adequate qualifications.

- Strongly encouraged - funds may be used to purchase a recommended file backup system.

New Reporting Requirements:

- If last year as LITC, explanation of steps to resolve current cases.

- Attach copies of special orders for student practice.

- Explanation of representation or referral where the amount in controversy exceeded the $\$ 50,000$ per tax year limit.

New Funding Requirements

- Nominal amount clarified: if it reduces the number of taxpayers able to be assisted, the amount is not nominal. 


\section{2 |Pittsburgh Tax Review | Vol. 182020}

PUB. 3319 FOR 2009

I.R.S. Pub. No. 3319, Low-Income Taxpayer Clinics 2009 Grant Application Package and Guidelines (2008).

Funding Requirements - Pro bono referral panel requirement added for ESL clinics: can refer to other LITCs, but no controversy funding if only referring to LITCs.

PUB. 3319 FOR 2010

I.R.S. Pub. No. 3319, Low-Income Taxpayer Clinic 2010 Grant Application Package and Guidelines (2009).

Reporting Requirements:

- Interim: detail if funds awarded will not be used entirely and estimate amount that will not be used.

- Interim: May submit a separate letter requesting additional funds at this stage with the interim report.

PUB. 3319 FOR 2011

I.R.S. Pub. No. 3319, Low-Income Taxpayer Clinic 2011 Grant Application Package and Guidelines (2010).

New Operational Requirements:

- $\quad$ Added very detailed discussion of media requests and the policies applicable to them.

New Reporting Requirements:

- Added requirement for discussion of success stories and emerging issues for both interim and year-end reports.

New Funding Requirements:

- Clarifying point added: Clinics cannot make subgrants to another organization for the services they are supposed to provide (controversy or ESL).

PUB. 3319 FOR 2012

I.R.S. Pub. No. 3319, Low-Income Taxpayer Clinics 2012 Grant Application Package and Guidelines (2011).

No revisions made.

Pitt Tax Review | ISSN 1932-1821 (print) 1932-1996 (online) DOI 10.5195/taxreview.2020.119 | http://taxreview.law.pitt.edu 
PUB. 3319 FOR 2013

I.R.S. Pub. No. 3319, Low-Income Taxpayer Clinics 2013 Grant Application Package and Guidelines (2012).

New Funding Requirements:

- Those clinics that are granted funding and that receive controversy funding as a part of that grant should be using the rate (as adjusted for inflation) that can be found in IRC $\S 7430$ to determine a value for donated services from qualified representatives.

- The publication offers additional guidance for those clinics operating a controversy program.

- Helps to determine a taxpayer's income eligibility for services.

- Consultations are now NOT SUBJECT to income eligibility requirements:

o Publication clearly states that the income eligibility requirement only applies to REPRESENTATION in controversy cases and not other activities.

PUB. 3319 FOR 2014

I.R.S. Pub. No. 3319, Low-Income Taxpayer Clinics 2014 Grant Application Package and Guidelines (2013).

New Procedure for Submitting LITC Grant Applications for NCCs:

- This is the first year that that applications were required to be submitted electronically through www.grants.gov.

- For all NCCs, applications were required to be submitted through www.grantsolutions.gov.

New Operational Requirements:

- Qualified Tax Expert (QTE) must be authorized to practice before the IRS.

o Previously, any individual demonstrating tax expertise because of a degree/experience/or CPE credits was permitted to be a QTE.

o Beginning with 2015, QTEs MUST BE ATTORNEYS, CPAs, OR ENROLLED AGENTS currently authorized to practice before the IRS.

Pitt Tax Review | ISSN 1932-1821 (print) 1932-1996 (online) DOI 10.5195/taxreview.2020.119 | http://taxreview.law.pitt.edu 


\section{4 | Pittsburgh Tax Review | Vol. 182020}

- 90/250 Requirement Applied per Case and Not Individual:

o Moving forward, if a clinic is representing both spouses with respect to joint liability in a case, clinics should count ONE taxpayer assisted for purposes of the $250 \%$ of federal poverty line requirement.

PUB. 3319 FOR 2015

I.R.S. Pub. No. 3319, Low-Income Taxpayer Clinics 2015 Grant Application Package and Guidelines (2014).

New Procedures:

- The grantsolutions.gov website is being more heavily utilized for this year.

- Grantees are instructed to use the website for all actions regarding the grant of funding moving forward, including but not limited to:

o Accepting notice of the award;

o Submitting a revised budget;

o Reporting changes in program plan;

o Reporting changes in staff;

o Filing interim reports;

o Filing year-end reports; and

o Submitting NCC requests for funding (this hasn't changed).

New Focus on Underserved Areas

- TAS points out several areas that could be served better.

- Particular states:

o Alabama;

o Alaska;

o Georgia;

o Kansas;

o Mississippi;

o North Dakota;

o South Dakota; and

o Puerto Rico.

- $\quad$ Specific Metropolitan Areas

o Los Angeles, California;

o Sacramento, California; and

o Northern Virginia (Arlington/Fairfax/Loudon/Prince William).

Pitt Tax Review | ISSN 1932-1821 (print) 1932-1996 (online) DOI 10.5195/taxreview.2020.119 | http://taxreview.law.pitt.edu 
New Funding Requirements:

OMB Uniform Guidance:

- Office of Management and Budget released new guidance in 2013 for federal awards.

- The guidance supersedes the requirements affecting LITC grants, and applies to fiscal years beginning after December 26, 2014.

- This new guidance will apply to 2015 LITC grants except for AUDIT REQUIREMENTS.

- Helps to ensure high level of integrity in financial management of grant programs

PUB. 3319 FOR 2016

I.R.S. Pub. No. 3319, Low-Income Taxpayer Clinics 2016 Grant Application Package and Guidelines (2015).

New Operational Requirement:

- "Providing Controversy and ESL Services under a Single Grant Award" (p. 2):

o First year that they no longer award funding to operate separate programs.

o All LITC grantees have to operate unified programs.

o If operating independently, will not be able to receive funding.

PUB. 3319 FOR 2017

I.R.S. Pub. No. 3319, Low-Income Taxpayer Clinics 2017 Grant Application Package and Guidelines (2016).

New Procedures:

- "Expansion of special appearance authorization authority to include recent law graduates." (p. iii)

- Director of LITC Program Office now has authority to issue special appearance authorizations for practice before IRS.

- Previously did not include law graduates between graduation and admission to a state bar.

- New Guidelines on Conflicts Policies:

o Applicants MUST HAVE written policy to manage conflicts of interest.

o Any potential conflict of interest must be disclosed to LITC program office. 


\section{$106 \mid$ Pittsburgh Tax Review | Vol. 182020}

PUB. 3319 FOR 2018

I.R.S. Pub. No. 3319, Low-Income Taxpayer Clinics 2018 Grant Application Package and Guidelines (2017).

New Procedures:

- Review of funded grantees submitting a continuation request.

- $\quad$ LITC Program Office lists what they consider when a LITC applies to renew.

o Things they consider:

- Timeliness, accuracy, completeness of interim and yearend reports;

- $\quad$ Significant concerns identified by site assistance visits and how they were addressed by the clinic;

- Whether grantee's activities match its program plan;

- Grantee's involvement with other tax clinics, community groups, TAS, and LITC Program Office;

- Whether grantee has history of not drawing down funds in timely manner; and

- Whether grantee failed to use all funds awarded in prior years.

PUB. 3319 FOR 2019

I.R.S. Pub. No. 3319, Low-Income Taxpayer Clinics 2019 Grant Application Package and Guidelines (2018).

Could not access this Pub. 3319.

PUB. 3319 FOR 2020

I.R.S. Pub. No. 3319, Low-Income Taxpayer Clinics 2020 Grant Application Package and Guidelines (2019).

New Procedures:

- Assurances and certifications change when renewing system for award management:

o When signing up, the certifications are automatically agreed to.

- List of Common Errors was Added.

o Some of those include:

- Standard Form 424: wrong end date when filling out a multi-year program plan to complete;

Pitt Tax Review | ISSN 1932-1821 (print) 1932-1996 (online) DOI 10.5195/taxreview.2020.119 | http://taxreview.law.pitt.edu 
- $\quad$ Form 13434-M: applicants indicate a single audit was qualified when it in fact was not; and

- Form 13434-J: applicants fail to state how many hours per week is considered full time.

- Also, no break down of travel and training expenses.

- EID and data universal number system number:

o Applicants fail to register early on SAM.gov.

o Usually takes eight weeks and must be completed before application deadline.

- Attachments:

o Incomplete copy of single audit is submitted and no copy submitted when unavailable to the LITC Program Office. 
